University of Redlands

\title{
Developing A Recreational Tour Map
}

A Major Individual Project submitted in partial satisfaction of the requirements for the degree of Master of Science in Geographic Information Systems

by

Fisal Basheeh

Ruijin Ma, Ph.D., Committee Chair

Nader Afzalan, Ph.D.

April 2016 
Developing A Recreational Tour Map

Copyright @ 2016

by

Fisal Basheeh 
The report of Fisal Abdullah Basheeh is approved.
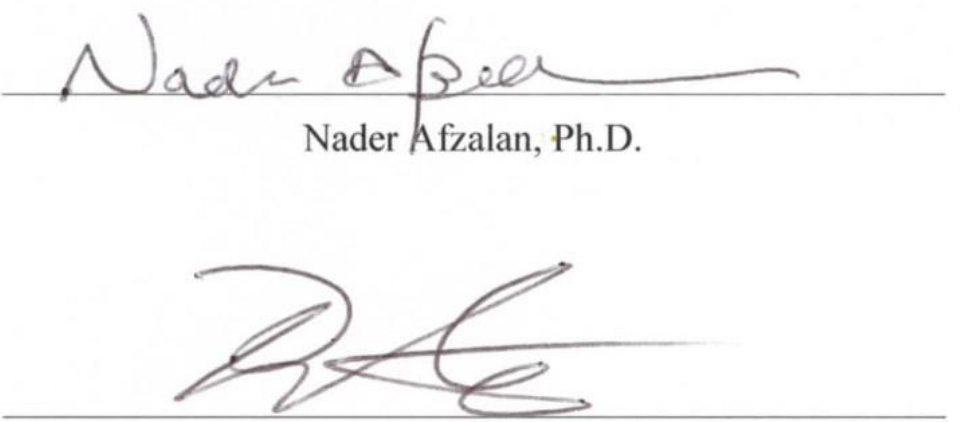

Ruijin Ma, Ph.D., Committee Chair

April 2016 


\section{Acknowledgements}

First of all, I thank Allah for everything. I hadn't thought that I'm going to continue my master degree abroad but my dream came true. I appreciate my parents - Abdullah and Haifa - who always look after me and lead me to the right decisions in my life. Very spatial thanks to my lovely wife - Hanan Makhdum - who was supporting me in this life and grateful moments we spent abroad.

Thanks to my awesome siblings - Mohammad, Masheal, Mrooj, and Noran - who are in my life every single day, even though I live in a different time zone.

I also thank Allah for having such an amazing brother Umar Makdoom, who is always next to me since middle school until he officially became my brother in-law. I couldn't live in a foreign country without his support.

Special thanks to my advisor, Dr. Ruijin Ma, for his advice, support and encouragement. Joseph, you were my closest international friend, thanks for your time being next to me when I need you. It is impossible to mention all people who influenced me in a positive way during my two-year program, you made me feel happy in this program. 


\section{Abstract \\ Developing A Recreational Tour Map}

by

Fisal Basheeh

This project developed alternative recreational trail map and elevation profile for Sonoma North Coast Protected Lands Complex (SNCPLC). The clients of this project were the Sonoma Land Trust and the Wildlands Conservancy. The recreational trail map was developed for three properties in Sonoma County: Little Black Mountain Preserve, Pole Mountain property, and Jenner Headlands Preserve. This alternative recreational trail map met the clients' need to monitor the properties. The project identified more opportunities use for more diverse groups of people. Suitability analysis and least cost path approach were implemented to determine suitable trail in the SNCPLC. This suitability analysis was performed using ArcGIS for Desktop 10.3. The project also included the creation of elevation profile and mileage computations for the suitable recreational trail highlighted in the final map design. 



\section{Table of Contents}

Chapter 1 - Introduction ..................................................................................... 1

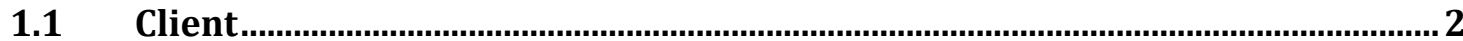

1.2 Problem Statement......................................................................................... 2

$1.3 \quad$ Proposed Solution...................................................................................... 3

1.3.1 Goals and Objectives .......................................................................................................... 3

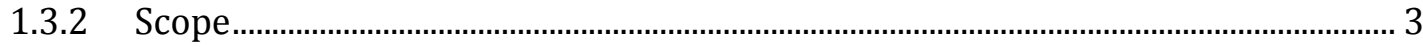

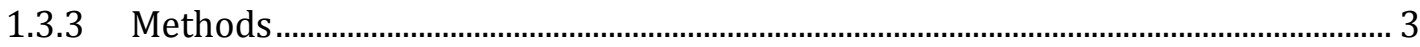

1.4 Audience ...................................................................................................... 4

1.5 Overview of the Rest of this Report .................................................................. 4

Chapter 2 - Background and Literature Review .................................................... 5

2.1 Suitability Analysis Methods for Land Management .......................................... 5

$2.2 \quad$ Recreational Trail Landmarks ............................................................................ 10

2.3 Summary ................................................................................................. 12

Chapter 3 - Systems Analysis and Design …….................................................13

3.1 Problem Statement........................................................................................ 13

3.2 Requirements Analysis ............................................................................... 13

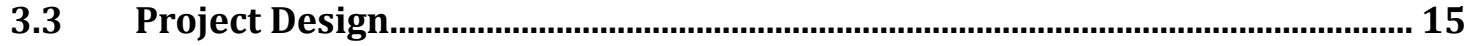

3.3.1 Identification of the Suitability Factors..................................................................15

3.3.2 Determination and Acquisition of the Project Data......................................................15

3.3.3 Creation of the Project Geodatabase Schema....................................................................15

3.3.4 Final Maps Design ..........................................................................................................15

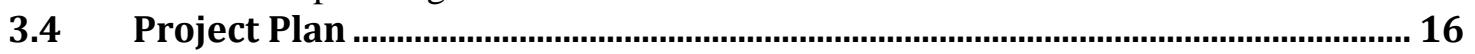

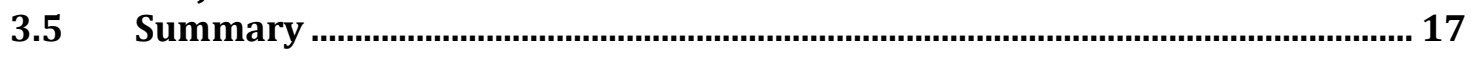

Chapter 4 - Database Design ...........................................................................19

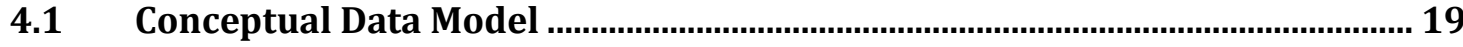

4.2 Logical Data Model............................................................................................. 20

4.3 Data Sources.................................................................................................. 22

4.4 Data Scrubbing and Loading ………........................................................... 22

4.5 Summary .................................................................................................... 22

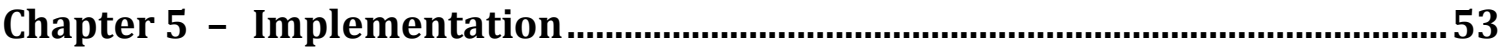

5.1 An Alternative Trail...................................................................................... 53

5.1.1 Data Reclassification ....................................................................................................5

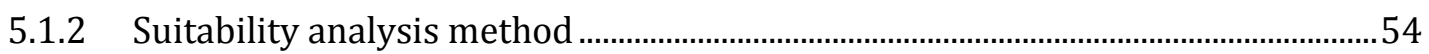

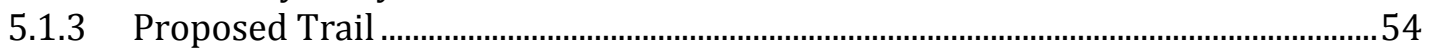

$5.2 \quad$ Tour Map …...................................................................................................... 54

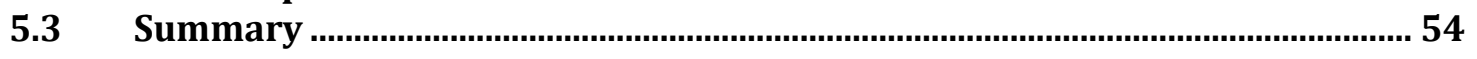

Chapter 6 - Results and Analysis .......................................................................54

6.1 Proposed Trail within the Suitable Zones ......................................................... 54

6.2 Final Map Design ........................................................................................ 54

6.3 Summary ............................................................................................................. 54

Chapter 7 - Conclusions and Future Work .........................................................54

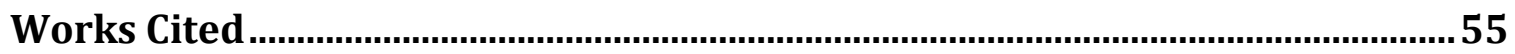




\section{Table of Figures}

Figure 1-1: Sonoma County and the three properties ................................................... 1

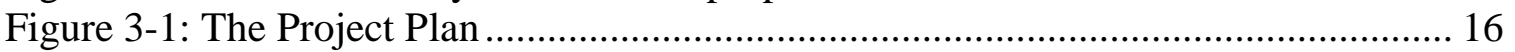

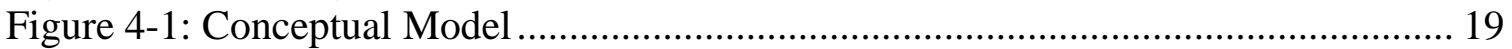

Figure 4-2: The Logical Data Model ....................................................................... 20

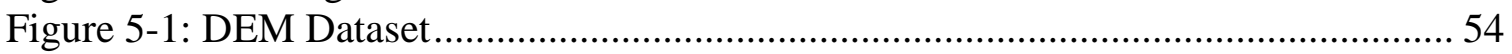

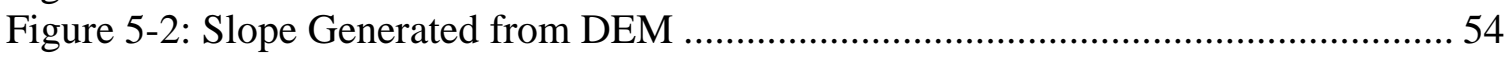

Figure 5-3: Slope Reclassification for the Suitability Analysis......................................... 54

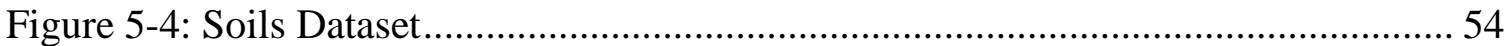

Figure 5-5: Land Cover of SNCPLC …………………........................................... 54

Figure 5-6: The Reclassification of the Land Cover....................................................... 54

Figure 5-7: The Influence Percentage for the Factors ................................................. 54

Figure 5-8: The Suitability Produced from Weighted Analysis ........................................ 54

Figure 5-9: The Existing Trail Dataset ..................................................................... 54

Figure 5-10: Calculating the Cost Surface Considering the Existing Trail ...................... 54

Figure 5-11: The Elevation Profile Tool..................................................................... 54

Figure 5-12: An example of A profile in Little Black Mountain....................................... 54

Figure 5-13: Contours with on Interval of 100 Feet ………........................................ 54

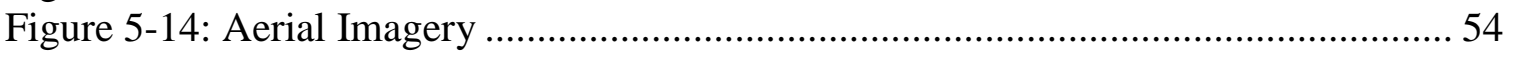

Figure 6-1: The Suitable and Non-Suitable Zones .......................................................... 54

Figure 6-2: The Existing Trail on An Aerial Image of SNCPLC .................................... 54

Figure 6-3: The Proposed Trail.............................................................................. 54

Figure 6-4: The Existing and the Proposed Trails ........................................................ 54

Figure 6-5: The Proposed Trail Map ……………………........................................ 54

Figure 6-6: The Proposed Trail on An imagery Basemap ................................................ 54

Figure 6-7: The Existing Trail on An imagery Basemap................................................ 54 


\section{List of Tables}

Table 2-1: The Factors Considered in Designing Recreatinal Trail Forest Dune Habitat (adopted from T. Sitzia, A. Rizzi, D. Cattaneo, \& P. Semenzato,2014)........................... 8 Table 2-2: Hiker/Pedestrian Design Parameters (adopted from U.S. Forest Service 2008)

10

Table 2-3: Pack and Saddle Design Parameter (adopted from U.S Forest Service2008).. 11

Table 3-1: Functional and Non-Functional Requirements............................................ 14

Table 4-1: The Logical Data Model............................................ 21

Table 5-1: Slope Reclassification for the Suitability Analysis ...................................... 54

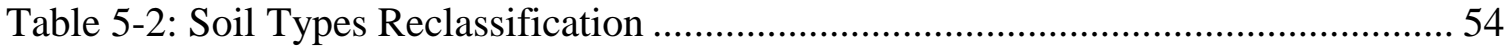

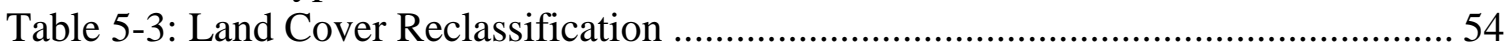





\section{List of Acronyms and Definitions}

$\begin{array}{ll}\text { DEM } & \text { Digital Elevation Model } \\ \text { GIS } & \text { Geographic information systems } \\ \text { GPS } & \text { Global position system } \\ \text { SLT } & \text { Sonoma Land Trust Organization } \\ \text { SNCPLC } & \text { Sonoma North Coast Protected Lands Complex } \\ \text { TWC } & \text { Wildlands Conservancy Organization }\end{array}$




\section{Chapter 1 - Introduction}

Recreation areas are enjoyed by many for exercise, recreation, and leisure. Wide open areas of the environment have been developed for recreational purposes. The Sonoma Land Trust (SLT) and The Wildlands Conservancy (TWC) organizations, located in Sonoma County in Northern California, needed recreational maps for their three properties: Little Black Mountain Preserve, Pole Mountain Property, and Jenner Headlands Preserve. Figure 1 shows the location of these three properties.

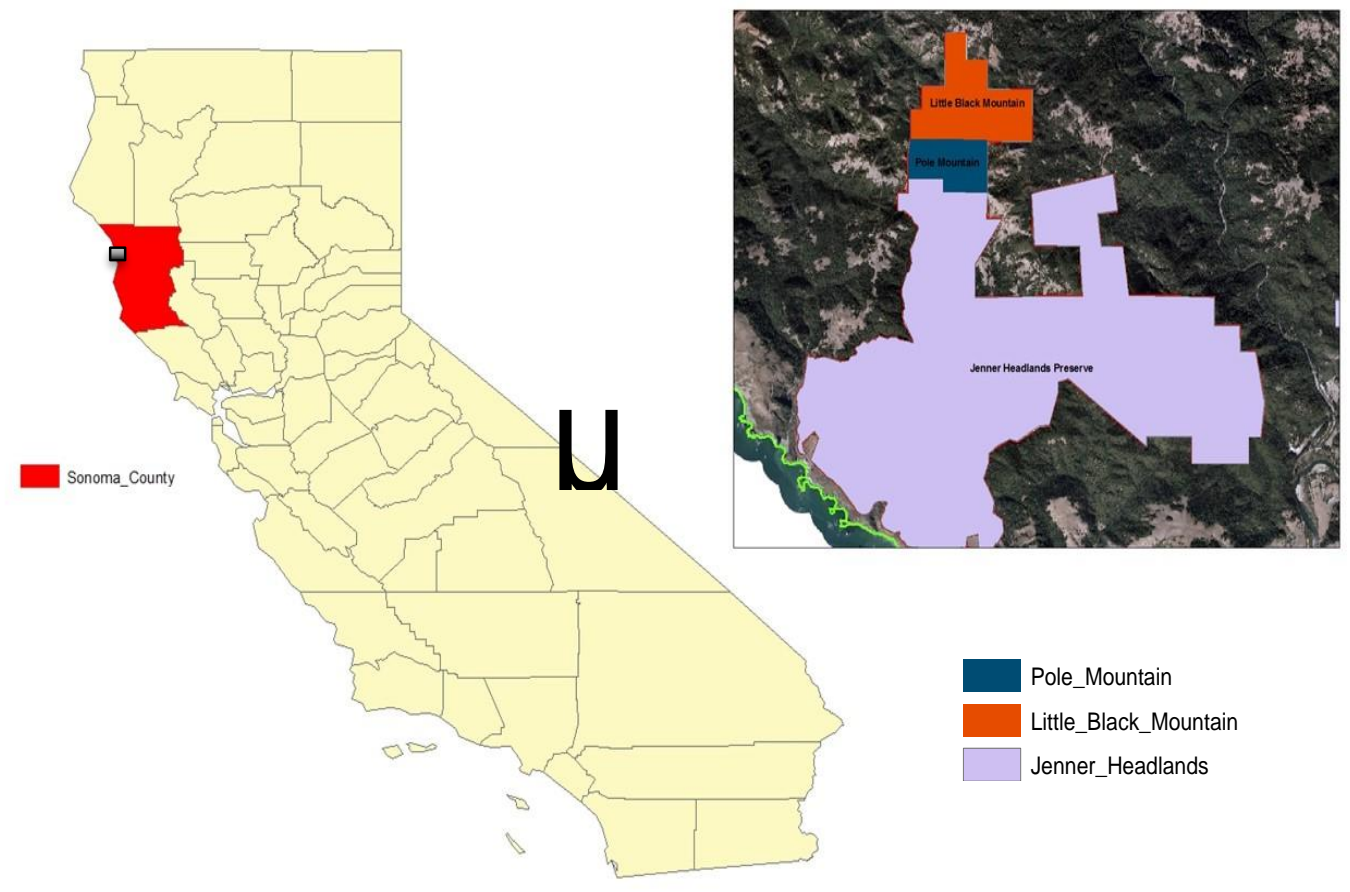

Figure 1-1: Sonoma County and the three properties 
This chapter is organized into five sections. Section 1.1 gives a brief description of the project clients; Section 1.2 discusses the clients' problem; Section 1.3 gives an overview of the proposed solution. This proposed solution was subdivided into goals and objectives, scope, and methods. Section 1.4 describes the target audience, and Section 1.5 outlines the structure of the rest of the project report.

\subsection{Client}

The Sonoma Land Trust (SLT) and the Wildlands Conservancy (TWC) were the clients for this project. Shanti Edwards from SLT and Brook Edwards from TWC served as the points of contact. The SLT "is a local, non-governmental, nonprofit organization funded largely by membership contributions" (Sonoma Land Trust, 2014). SLT's mission is to "protect the scenic, natural, cultural, agricultural, and open lands of Sonoma County for the benefit of future generations" (Sonoma Land Trust, 2014). "SLT owns and operates California's largest nonprofit nature preserve system, which includes 12 magnificent landscapes spanning over 145,000 acres of diverse mountain, valley, desert, river, and ocean front properties" (The Wildlands Conservancy, 1995-2012). The clients provided all data needed for the project.

\subsection{Problem Statement}

The Sonoma North Coast Protected Lands Complex (SNCPLC) lacked a tour map of recreational trails for use by visitors. The clients needed a way to determine the most suitable recreational trail in SNCPLC. "The 500-acre Black Mountain Preserve was donated to Sonoma Land Trust in 1979, the 238-acre Pole Mountain Property was acquired by Sonoma Land Trust in 2014, and the 5630-acre Jenner Headlands Property was acquired in 2009 by Sonoma Land Trust" (Sonoma Land Trust, 2014). This project was implemented to develop a single map for recreational trails in the SNCPLC using several factors. The clients also wanted to use GIS to create elevation profiles for the recreational trails. These profiles would help visitors choose a trail to hike based on the

elevation. The clients also needed the computation and graphic representation of the trail mileage. 


\subsection{Proposed Solution}

To determine the optimal recreational trail for the SNCPLC, a suitability analysis was proposed. GIS technology presented the best option, as it provided a platform with which to overlay weighted landscape layers for optimal suitability analyses. A least cost path methodology was employed to determine the effort required to hike different trails within the facilities. These analyses yielded graphical outputs as hard copy maps, which proved useful for visiting hikers. Each factor considered in the suitability analysis was then put on a map as an individual layer to highlight its importance. The results were then used to develop a map highlighting the identified trails within the SNPCLC. Each recreational trail featured an elevation profile and mileage graph.

\subsubsection{Goals and Objectives}

This project's primary goal was to employ GIS technology to perform a suitability analysis to identify suitable recreational trail for SNCPLC. This goal was achieved through the following objectives:

- Identifying the appropriate suitability analysis factors for the SNCPLC

- Building a geodatabase of the identified suitability analysis factors

- Creating a recreational map, elevation profile, and mileage for the proposed recreational trail

\subsubsection{Scope}

This project sought to develop a recreational map and elevation profile highlighting the suitable recreational trail for the SNCPLC. Completion of the project required the creation of a map on ArcGIS for Desktop 10.3. The suitability analysis was performed using the tools in ArcGIS for Desktop 10.3, ArcToolbox. The project encompassed the creation of an elevation profile and mileage computations for the recreational trail identified by the clients. The elevation profile was provided as a graphic image for the trail, and the mileage and elevation were delivered to the client in tabular format. The final map products were provided as map packages and 36"x 36" printed copies. This project did not involve the creation of web maps, geoprocessing models, or any scripts.

\subsubsection{Methods}

This project utilized GIS technology to perform a suitability analysis to aid in SNCPLC's planning process. The project relied on Esri's ArcGIS for Desktop 10.3 for the suitability analysis, as well as the generation of the final product - a recreational map and an elevation profile of a suitable trail. While the clients provided some of the project data, the Internet was used to acquire the supplemental data that were not available at the time of execution. This supplemental data included digital elevation models (DEMs), which were used to calculate some required factors (e.g, the slope for the suitability analysis). All the data were hosted in a file geodatabase. Since the project involved both vector and raster data, feature classes and a raster dataset format were used for the different data formats respectively. ArcCatalog was used to design and load the file geodatabase, and ArcMap was used to develop the map. 
To identify the suitable recreational trail, a suitability analysis and a least cost path analysis were performed using Spatial Analyst extension tools in ArcGIS for Desktop 10.3. Various scenarios were developed to determine the weighted overlay analysis options for the possible trails around the complex. This weighted overlay analysis used these scenarios to weight the factors including slope, soil type, and land cover in different ways for generating the optional recreational trail for the complex.

The weighted overlay analysis is usually performed using raster data, so the data representing the factors being considered in the weighted overlay analysis were converted to raster format. Next, the least cost path method was applied to determine the most suitable trail. The resulting trail was then converted back to vector data for use in the clients' recreational maps.

\subsection{Audience}

Two audiences were targeted during the execution of this project. The SLT and TWC staff, who would use the trail to perform facility maintenance, comprised the first audience. Also, the staff are involved in data collection using a hand held GPS, and the creation of the trail would help them know where to put their focus for the best results. The second audience was the public, who will use the map for recreational activities.

\subsection{Overview of the Rest of this Report}

The rest of this report is organized into six chapters. Chapter 2 is the literature review. The system analysis and design of the project are elaborated in Chapter 3, together with analysis requirements and the project plan. Chapter 4 explains both the conceptual and logic data models used in the project, and includes the data source and collection method used in this project. The process of developing the recreational trail is discussed in Chapter 5. Chapter 6 shows the results, including the recreational map for SNPCLC and the weighted overlay analysis results of the project. The conclusion of the report and suggestions for future work are in Chapter 7. 


\section{Chapter 2 - Background and Literature Review}

As population growth and industrialization have exploded, the environment has correspondingly felt the adverse effects if these changes. Environmental change affects all corners of the world - urban and rural, rich and poor. As the population grows, societies struggle to find and maintain areas for recreational activities. Natural resources are under a lot of pressure at the global as well as the local scale. One region where the changes are acutely experiences is Sonoma County, CA. There is therefore a need for strategies that utilize current and advanced technology to better manage the available resources so that they can support the needs arising from the growth of population and related demands.

In these areas, GIS has proven its value in environment and resource management. This project relied on GIS technology to explore the suitable areas for recreational trail for the SCNCPLC in Sonoma County. Geospatial techniques were implemented to discover a suitable trail that was optimal for the recreational needs of the SNCPLC.

\subsection{Suitability Analysis Methods for Land Management}

Suitability analysis has widely been used to solve land management problems. Since it is part of spatial analysis techniques, suitability analysis offers various options for solving the problem. Therefore, it was the best suited approach for determining the best solution for this issue. Spatial suitability analysis was found as a reliable method based on research from previous projects, a few of which are discussed below.

First, Nagarajan and Singh conducted a study to determine groundwater potential zones (2009). The main goal was to use the weighted overlay analysis in ArcGIS desktop to help classify the groundwater potential zones. The weighted overlay analysis took into consideration thematic factors like geology, geomorphology, soil hydrology, land use, and land cover. Nagarajan and Singh (2009) ranked different thematic factors and assigned each factor a certain weight influence. The study generated three categories for the groundwater potential zones: good, moderate, and poor. For the purposes of results validation, sample wells were selected and mapped on the ground in each of the three categories identified from the weighted overlay analysis. The sampled wells provided a basis of evaluating the analysis results. The sampled wells were found in the appropriate category as designated by the analysis thus proving the validity of the analysis conducted during the study.

During the Virginia Parks and Recreation Society's 54 ${ }^{\text {th }}$ conference, Futrell and LaRoche (2015) presented results from their research on GIS and GPS for Recreational Trail Planning and Design in Wild-land Settings. This study used GIS and GPS in designing the trail in wild land. Their research began by collecting data through field survey, which they then used to build a GIS database. They also employed additional types of data, including aerial images, exiting trail, vegetation type and points of interests. In the analysis stage, both slope and aspect were generated from DEM and considered in the process of designing the trail. Additionally, vegetation data were used in relation to the aspect factor for determining the best trail. After implementing the weighted overlay analysis, a GPS device was then used to map the trail and collecting 
points of interest. This was a results validation process for the results generated from the spatial suitability analysis.

Another study utilizing suitability analysis was conducted by Sattler (2014). She used GIS technology to conduct a management study of an 800 -acre property owned by the Bartlett Hills Association (BHA). During this study, Sattler created a suitability analysis model in Model Builder, which helped to highlight new recreational trails within the BHA property for recreational purposes. Sattler used GIS to help manage the property and assist in the maintenance of the forest and prairies. Applying the weighted overlay analysis led to the identification of the area where the recreational trails should be within the property. Moreover, the sustainability model for the trails was built based on cost path analysis by calculating cost surface. This approach determined the cost distance, which was then evaluated to determine the least cost area where the trails were proposed to be constructed. The suitable trails were identified based on three environmental factors: slope, soil type, and forest type. Sattler added a class field as feature attribute to the dataset for the factors considered in the analysis.

Sattler (2014) reclassified the classes in the feature classes, assigning numbers to represent the suitability of building a hiking trail. These class ranged from one (the most suitable) to five (least suitable). The slope factor was reclassified based on degrees. She classified the areas with the least gradient (non-steep areas) as the most suitable areas for the trails while the high gradient (steep slopes) as the most unsuitable areas. According to Sattler, this was because the steep areas were very vulnerable to soil erosion as compared to non-steep areas. In addition, any slope degree greater than thirty-five was regarded as risky and difficult to hike.

Both soil type and slope were given forty percent weight in the weighted overlay analysis because they had a larger influence to determine the area for suitable trail based on their criteria (Sattler, 2014). After the weighted overlay analysis, cost surface analysis was performed, which implemented the least cost path from the start point to different points of interest considered in the project. Completion of the project saw the creation of nine maps, each highlighting different outputs of the project. For example, some of the maps included Sustainable Trail Suitability map, 3D Terrain Model, and Sample Point of Interest in the Field.

Past studies have used similar techniques to solve spatial problems. These studies provide an overview of the problem and similar approaches applied in comparable projects. For example, weighted overly analysis was used for the studies above to come up with a solution for different projects that required suitability analysis. Nagarajan and Singh (2009) developed different thematic maps to highlight the groundwater zones in Kattaklathur block, India based on weighted overlay analysis. Moreover, the Bartlett Hills property (Sattler, 2014) project used same technique in applying the weighted overlay analysis for highlighting and developing a suitable model which helped to highlight a suitable recreational trails. Based on these studies, it is evident that the same spatial techniques can be used to solve different spatial problems that are using same concept. However, each spatial problem should be thoroughly analyzed to ensure that the factors used are relevant and geared towards answering the question. 
A site suitability search for landfill in Charlotte County, Florida was conducted by Thompson (2014). This study applied weighted overlay analysis. "The amount of landfill have dramatically decreased since the 1980's" (Thompson, 2014). Students at University of Illinois decided to locate a best site suitable for landfill and applied suitability analysis to find the most appropriate site. The weighted overlay analysis was used to determine the sites. The factors used in this study were FEMA flood zones, soil type, existing land use, future land use, streets, and vulnerability to storm surge. All factors were classified to value of 1 or 0 . They then applied the raster calculator where they multiplied the cell of each input raster by the weighted needs and importance to the site. This process showed that most of the area in the middle was unsuitable, while the most suitable zones were located east of the study area.

A study by Abushnaf, Spence, and Rotherham (2013) of Libyan agricultural crop considered several factors and criteria that could be represented independently. "The principle problem of suitability analysis is to measure both the individual and cumulative effects of the different factors" (Abushnaf, Spence, \& Rotherham, 2013). Weighted overlay analysis was used in this project because it was able to work with different types of raster inputs and combine them to get one final map result. The study featured 14 suitable layers, and each one of them was considered as a map itself. The methodology of processing the weighted overlay analysis divided the process into various steps. This began with the reclassification of the layers into four classes following the structure of FAO: high suitable S-1, moderately suitable S-2, marginally suitable S-3, and not suitable S-4. Additionally, reclassifying the cell of each input raster as 4 for the most suitable and 1 for the least suitable. Lastly, inputs were weighted differently based of the project model. 
Another study using least-cost path analysis to design recreational trails in a forest dune habitat at the resolution of visitor sight distance was conducted by Sitzia, Rizzi, Cattaneo, and Semenzato (2014). Forest dunes are usually designed for recreational trails; however, because this kind of environment contains sensitive types of soil and vegetation, the design must be carefully done. Two GIS methods were employed to define the path in dune plantation forests: suitability analysis and least cost path. The suitability analysis was based on cells surveyed in the field. This field survey was used as data collection to build database to develop the trail. Table 2-1 illustrates all factors considered.

Table 2-1: The Factors Considered in Designing Recreatinal Trail Forest Dune Habitat (adopted from T.Sitzia, A. Rizzi, D. Cattaneo, \& P. Semenzato, 2014)

\begin{tabular}{|c|c|}
\hline \multicolumn{2}{|l|}{ Set of factors } \\
\hline \multirow{2}{*}{$\begin{array}{l}\text { Plant species } \\
\text { Diversity }\end{array}$} & Herbaceous species richness \\
\hline & Native woody species richness \\
\hline \multirow{3}{*}{ Habitat diversity } & Alien woody species richness \\
\hline & Natural areal features \\
\hline & Natural point features \\
\hline \multirow{2}{*}{ Stand structural } & Natural linear features \\
\hline & \begin{tabular}{|l} 
Diversity of the canopy cover \\
.
\end{tabular} \\
\hline Diversity & Diversity of the stand type \\
\hline \multirow[t]{2}{*}{ Ecological } & Natural dead wood \\
\hline & Natural regeneration \\
\hline \multirow[t]{4}{*}{ Geomorphological features } & Seed donor tress \\
\hline & Seed donor trees \\
\hline & Natural features \\
\hline & Artificial features \\
\hline
\end{tabular}

These factors were weighted differently in raster as cells. Each cell's value depended on the trail's priority. As implementation of the analysis began, the standard deviation was the measured to calculate the value of the cells. Least cost path was applied in this project based on cells with lower value to reduce both cost and time. 
Weighted overlay analysis "is a type of suitability analysis that helps you analyze site conditions based on multiple criteria" (esri, 2016). For applying the weighted analysis, all the factors should be given different weights based on their importance to the analysis.

"Each criterion must be reclassified into a common preference scale such as 1 to 10, with 10 being the most favorable" (esri, 2016). These criteria normally are not equal in importance so as to yield the right results. This importance determines the weight given to each factor and is dependent on the subject expertise for the suitability model being developed. For example, in this project slope was the main factor to be considered in the weighted analysis so it got a high percentage in the analysis than the other factors. The weighted overlay analysis workflow was divided into three steps. "First, each raster layer was assigned a weight, as a percentage, in the analysis. Second, values within each raster layer were mapped to a common suitability scale. Third, all raster layers in the analysis were overlaid" (esri, 2016). In this stage, the overlay analysis model multiplies each cell of the layer with the layer weight and then the values were added with the values of other raster cells. 


\subsection{Recreational Trail Landmarks}

A main component of developing recreational trails is illustrating and highlighting the fundamental base parameters for the trail construction. This section provides a helpful information from U.S. Forest Service Trails Management Handbook (2008) to identify the concepts of developing the recreational trails. In Section 14 of the Handbook, the Forest Service outlines five main fundamentals concepts of trails: Trail Type, Trail Class, Managed Use, Designed Use, and Design Parameters. These concepts are used to aid the identification, communication, and implementation of the trail management objectives.

In Section 23 of the Handbook, the Forest Service determined the parameters for the different types of trails such as Hiker/Pedestrian Design Parameters, Pack and Saddle Design Parameters, and Bicycle Design Parameters. Table 2-2 shows the basic hiker/pedestrian design parameters trail design from Section 23.11 of the Handbook:

\section{Table 2-2: Hiker/Pedestrian Design Parameters (adopted from U.S. Forest Service Trails} Management, 2008)

\begin{tabular}{|l|c|c|c|c|c|}
\hline Design Use & & & & \\
HIKER/PEDESTRIAN & Trail Class 1 & Trail Class 2 & Trail Class 32 & Trail Class 42 & Trail Class 52 \\
\hline & & & & & \\
\hline Design Grade & $5 \%-25 \%$ & $5 \%-18 \%$ & $3 \%-12 \%$ & $2 \%-10 \%$ & $2 \%-5 \%$ \\
\hline Design Cross Slope & Natural side & $5 \%-20 \%$ & $5 \%-10 \%$ & $3 \%-7 \%$ & $2 \%-3 \%$ \\
\hline Dlope & $6^{\prime}$ & $6^{\prime}-7^{\prime}$ & $7^{\prime}-8^{\prime}$ & $8^{\prime}-10^{\prime}$ & $8^{\prime}-10^{\prime}$ \\
\hline Design Turn & No minimum & $2^{\prime}-3^{\prime}$ & $3^{\prime}-6^{\prime}$ & $4^{\prime}-8^{\prime}$ & $6^{\prime}-8^{\prime}$ \\
\hline
\end{tabular}


Table 2-3 illustrates the table, adopted from Section 23.12 of the Handbook, providing the Pack and Saddle Trail Design Parameters:

Table 2-3: Pack and Saddle Design Parameter (adopted from U.S. Forest Service Trails Management, 2008)

\begin{tabular}{|c|c|c|c|c|c|c|}
\hline \multicolumn{2}{|c|}{$\begin{array}{l}\text { Design Use } \\
\text { PACK AND SADDLE }\end{array}$} & Trail Class 1 & Trail Class 2 & Trail Class $3^{2}$ & Trail Class $4^{2}$ & Trail Class $5^{2}$ \\
\hline \multirow{3}{*}{$\begin{array}{l}\text { Design } \\
\text { Tread } \\
\text { Width }\end{array}$} & Wilderness & \multirow{4}{*}{$\begin{array}{l}\text { Typically not } \\
\text { designed or } \\
\text { actively } \\
\text { managed for } \\
\text { equestrians }\end{array}$} & $12 "$ - 18" & $18 "$ - 24" & $24 "$ & \multirow{4}{*}{$\begin{array}{l}\text { Typically } \\
\text { not } \\
\text { designed or } \\
\text { actively } \\
\text { managed } \\
\text { for } \\
\text { equestrians }\end{array}$} \\
\hline & $\begin{array}{l}\text { Non- } \\
\text { wilderness } \\
\text { (Single Lane) }\end{array}$ & & $12 "$ - 24" & $18 "$ - 48" & $24 "$ - 96" & \\
\hline & $\begin{array}{l}\text { Non- } \\
\text { wilderness } \\
\text { (Double Lane) }\end{array}$ & & $60 "$ & $60 "$ - 84" & $84 "$ - 120" & \\
\hline $\begin{array}{l}\text { Design } \\
\text { Surface }^{2}\end{array}$ & Type & & $\begin{array}{l}\text { Native, with } \\
\text { limited } \\
\text { grading }\end{array}$ & $\begin{array}{l}\text { Intermittently } \\
\text { rough }\end{array}$ & $\begin{array}{l}\text { Minor } \\
\text { roughness }\end{array}$ & \\
\hline
\end{tabular}

The principle of developing recreational trail is based on understanding the recreational flow. Murdock (2004) conducted a study to understand recreation flow to protect wilderness resources at Joshua Tree National Park. "A comprehensive understanding of recreation flow allows fixed anchor regulations and wilderness management to address site-specific issues"(Murdock,2004, p.120). The methodology was essentially focused on balancing the number of visitors in the wilderness with the impact on natural resources. By applying GIS methods, a database containing all routes and trails was created and the routes mostly visited as well as the impact on the surrounding areas were analyzed. 


\subsection{Summary}

All of these previous studies helped to determine the best method of applying suitable analysis to the SNCPLC. Specifically, GIS techniques allow the combination and overlay of various factors to come up with the suitable result like a landfill site, recreational trail, etc. Additionally, applying the suitability analysis method into the project is a proven approach to help the clients with their planning needs. Sattler's is project (2014) provided an effective method for applying suitability analysis to develop a recreational trail in BHA. Also, the U.S. Forest Service Handbook shows the basic recreational trail basic hiker/pedestrian design parameters for constructing sustainable trails. 


\section{Chapter 3 - Systems Analysis and Design}

This chapter sets out the project requirements and system design. The project requirements are further categorized into functional and non-functional requirements. Also highlighted are other key components of the project, including the problem statement and project plan. This chapter is divided into four sections. Section 3.1 talks about the client's need and purpose for initiating the project. The analysis requirements is discussed and outlined in section 3.2 while Section 3.3 describes the system design. The project plan and schedule is illustrated in Section 3.4. Section 3.5 summarizes the chapter.

\subsection{Problem Statement}

The Sonoma North Coast Protected Lands Complex (SNCPLC) needed to identify the suitable areas to develop a recreational trail within the SNCPLC. Additionally, they needed a tour map with a graphic image of the elevation change profile and mileage for the trail. Considering several factors, this project implemented weighted overlay analysis approach to determine the least cost path for developing the required trail. The results were then used to author a map representing the identified trail with the elevation profile and mileages along the trail also shown on the map.

\subsection{Requirements Analysis}

A requirements gathering and needs assessment had to be conducted to assist SNCPLC in discovering the best solution for the problem above. This process helped narrow down the project's scope and hone in on the right solution to offer for the SNCPLC while ensuring that the clients' needs were met. After the requirements were gathered and analyzed, two broad categories were identified: functional and non-functional requirements. The functional requirements set out the specific things that the system would do when instigated by the user. On the other hand, the non-functional requirements are the foundational things that supported the execution of the functional requirements. These are the procedural things that explained how the system would work. 
Table 3.1. Functional and Non-Functional Requirements.

\begin{tabular}{|l|c|l|}
\hline \multicolumn{1}{|c|}{ Requirement } & Type & \multicolumn{1}{|c|}{ Description } \\
\hline $\begin{array}{l}\text { The system provided a suitable } \\
\text { trail between three properties }\end{array}$ & F & $\begin{array}{l}\text { Both staff and audience were } \\
\text { be able to see and explore the } \\
\text { proposed trails for } \\
\text { implementation within the } \\
\text { three properties }\end{array}$ \\
\hline $\begin{array}{l}\text { A map providing a graphic } \\
\text { elevation profile for the trail }\end{array}$ & F & $\begin{array}{l}\text { The proposed trail had an } \\
\text { elevation profile with it. This } \\
\text { helped comparing the } \\
\text { elevation changes for the } \\
\text { identified trail so that the } \\
\text { clients can provide it in the } \\
\text { map. }\end{array}$ \\
\hline $\begin{array}{l}\text { A map providing mileage for } \\
\text { the proposed trail }\end{array}$ & F & $\begin{array}{l}\text { This helped to give the } \\
\text { information about the } \\
\text { mileage. }\end{array}$ \\
\hline $\begin{array}{l}\text { All the analysis was performed } \\
\text { on desktop GIS application } \\
\text { (ArcGIS Desktop) }\end{array}$ & NF & $\begin{array}{l}\text { ArcGIS for Desktop was used } \\
\text { for conducting all the } \\
\text { necessary analysis and } \\
\text { producing all the results }\end{array}$ \\
\hline $\begin{array}{l}\text { Results were delivered to the } \\
\text { client as a file geodatabase, a } \\
\text { map package, and 36" by 36" } \\
\text { printed maps }\end{array}$ & NF & $\begin{array}{l}\text { This enabled the client have } \\
\text { final result as printed map as } \\
\text { well as a database to allow } \\
\text { them be able to re-run the } \\
\text { analysis using different } \\
\text { parameters for the factors } \\
\text { used in the weighted analysis, } \\
\text { if needed }\end{array}$ \\
\hline
\end{tabular}




\subsection{Project Design}

The design phase was essentially the planning and decision-making stage on how the project was to be carried out. This was the stage in which the clients' input was highly instrumental, because it involved the identification of the project factors as well as proper scope definition. The major tasks in this stage included:

a. Identification of suitability analysis factors

b. Data acquisition

c. Geodatabase schema development.

d. Final map design

\subsubsection{Identification of the Suitability Factors}

The project suitability analysis involved various factors that were weighted individually to achieve the required results. Different possible trails in the SNCPLC were achieved by weighing different factors. The primary factors identified included:

- Soil type

- Slope

- Land cover

\subsubsection{Determination and Acquisition of the Project Data}

This task involved the identification of the required datasets based on the project factors identified in Section 3.3.1. The data were acquired from the clients. The sufficiency and adequacy of these data were evaluated against the factors to see if there were any missing datasets to be acquired. This evaluation yielded the results that more data were needed. These other data were then sourced from the Internet. Section 4.3 elaborates more on the project data sources.

\subsubsection{Creation of the Project Geodatabase Schema}

To ensure that the project delivers a repeatable output, dependable database design was crucial. This involved the designing of a database schema that the project followed for organizing the data. This was helpful for the client to repeat in the future for their data design and storage for similar workflows. This schema development was achieved using ArcGIS for Desktop 10.3.

\subsubsection{Final Maps Design}

This task involved the identification of the final maps specifications. It outlined the specific format of the final maps as well as the paper type and size of the map. The map required that the identified trail overlaid on a basemap. Components included elevation profile, trail, mileage and other map components (legend, scale, north arrow, etc.). The map was printed on a 36"-36" piece of glossy paper. This map was to be used as a tool to plan public access to the SNCPLC. 


\subsection{Project Plan}

This section outlines the project schedule and planning. The major phases to achieve the successful result in developing recreational trail for SNCPLC were as follows: plan, design, development, and deployment. The first phase involved determining the scope of the project to help identify the project requirements and the client's needs for this project. Next, the design phase started the decision-making on how the project would be carried out. The third phase was the implementation stage of the project, which involved building of the final geodatabase and performing the data transfer into this final database. These phases also included the performance of the different weighted overlay analyses and the least cost path to identify the suitable trail. The last phase was the deployment stage where the map was authored, printed and all deliverables delivered to the clients. It was during this stage that the project document and final poster were done and submitted to the faculty. The project plan strategy is illustrated in Figure 3-1.

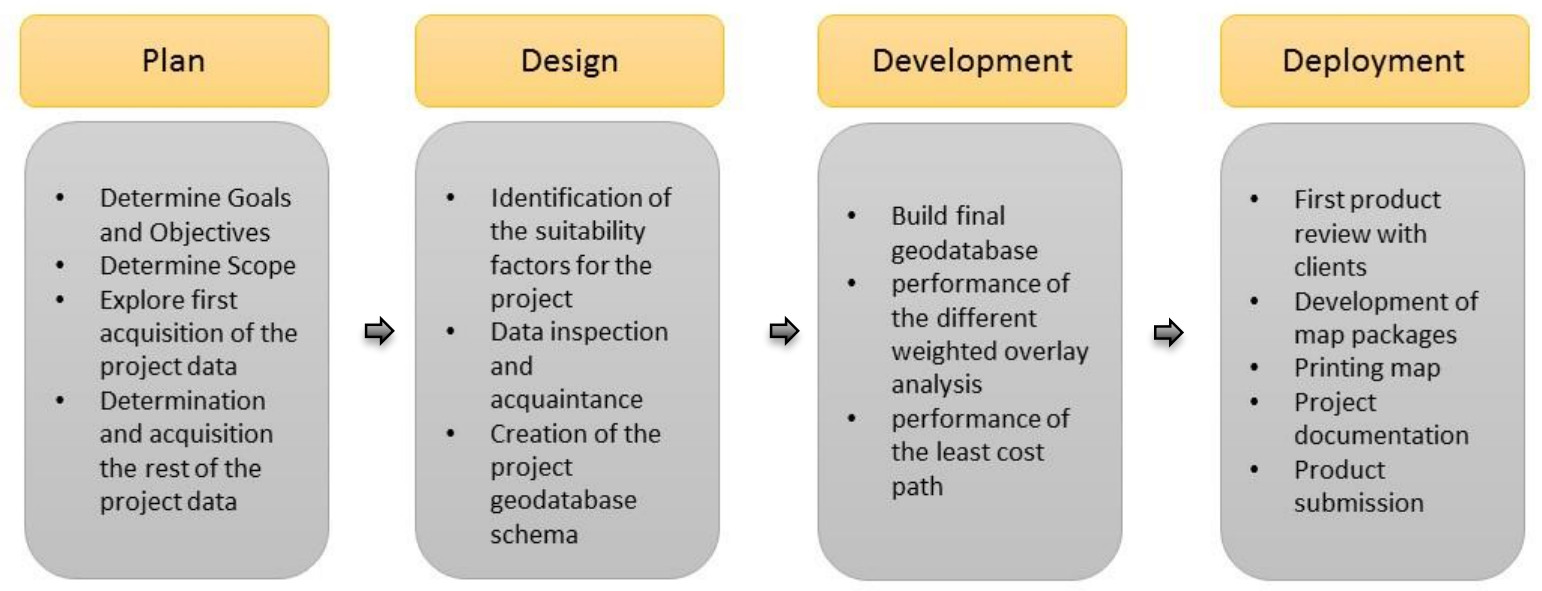

Figure 3-1: The Project Plan 


\subsection{Summary}

This chapter showed the methodology for developing the recreational trail in the SNCPLC and featured a discussion of the problem statement, requirements analysis, system design, and project plan. The project requirements were divided into two parts: functional and non-functional requirements. The project plan included four phases: planning, design, development, and deployment. 


\section{Chapter 4 - Database Design}

This chapter is a discussion of the database structure and development for the project completed for the Jenner Headlands, Pole Mountain, and Little Black Mountain properties located in Sonoma County North Coast Protected Lands Complex (SNCPLC). To suitably and appropriately execute the project, a database had to be designed to house the framework into which the project data would be loaded. This chapter is organized into six sections to discuss the data used in this project. Section 4.1 discusses the conceptual model of the project database. The logical model designed for the project to determine the suitable recreational trail for planning purposes in the SNCPLC is illustrated in Section 4.2. Section 4.3 discusses the sources of the data used in this project. Section 4.4 discusses the spatial reference used for the data and the process of scrubbing and loading the data. Finally a brief description of this chapter is provided in section 4.5.

\subsection{Conceptual Data Model}

The project aimed at identifying the suitable trail that could be developed for recreational purposes for the SNCPLC. To accomplish this, various factors had to be defined to establish the suitable area for a recreational trail. A suitability analysis was run based on the identified factors to locate the most suitable trail for development. he inputs for the weighted overlay analysis must be raster datasets. All the factors to be considered in this analysis were represented in raster format. The vector data included points of interest, relationship network, and contours. On the other hand, all the factors in raster included slope, soil type, and land cover. All the factors were classified before the suitability analysis was applied to determine the suitable zones. The final product was maps highlighting the proposed trail and existing trails. This maps included elevation profiles for the trails and the mileage as well. After the final suitable areas for the trail have been identified, the results were converted to vector format. Figure 4-1 shows the conceptual model of the project data. 


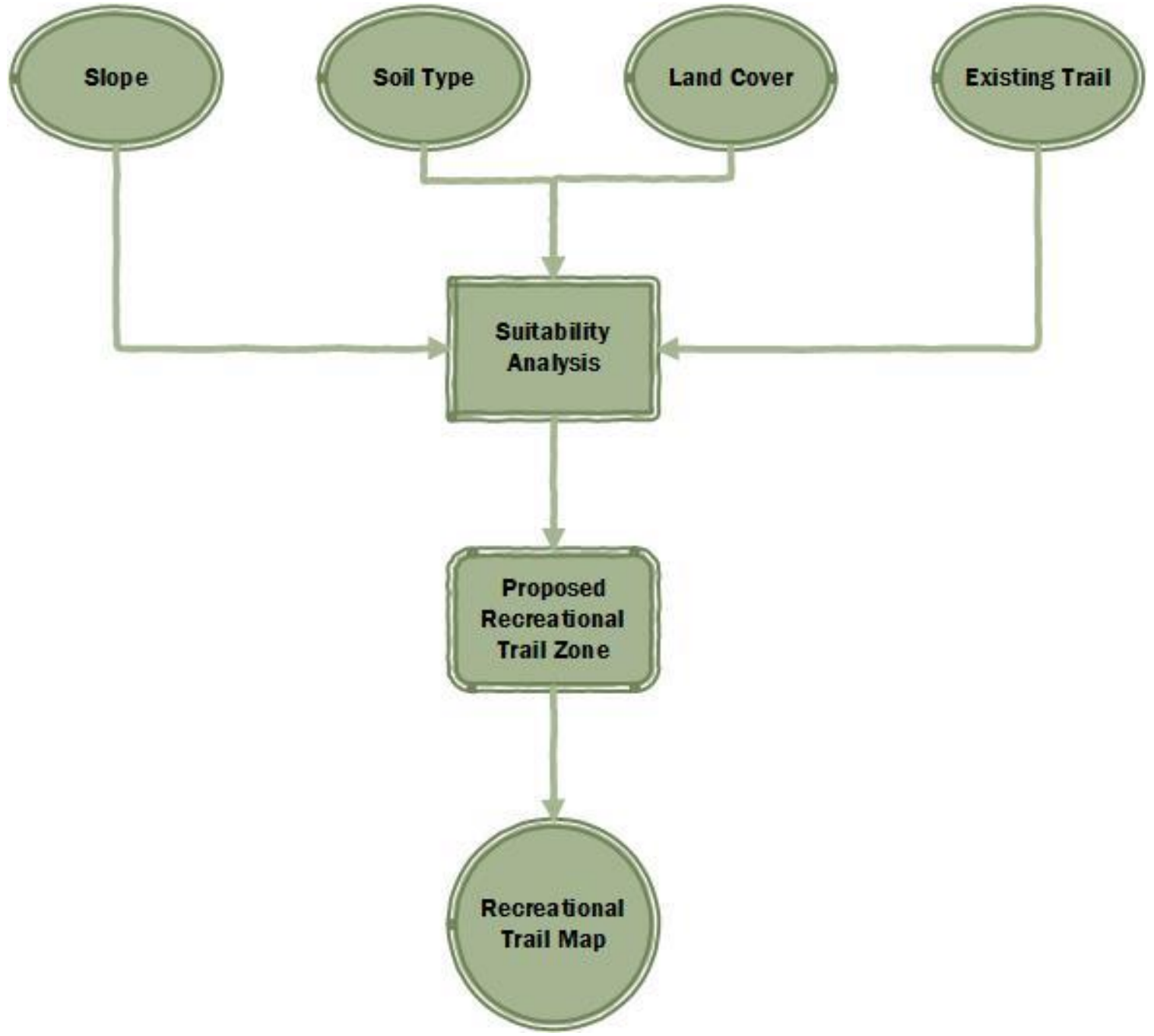

Figure 4-1: Conceptual Model 


\subsection{Logical Data Model}

The logical data model shows more details about the data relationship and the data used to implement the project. The required datasets included a 1-meter Hydro flattened Bare Earth DEM, property boundaries, streams, contours for the elevation, roads and existing trails. For this project points of interest were developed including parking areas, trail signs, restrooms, water sources, picnic tables, study area boundary, existing trails, and contours.
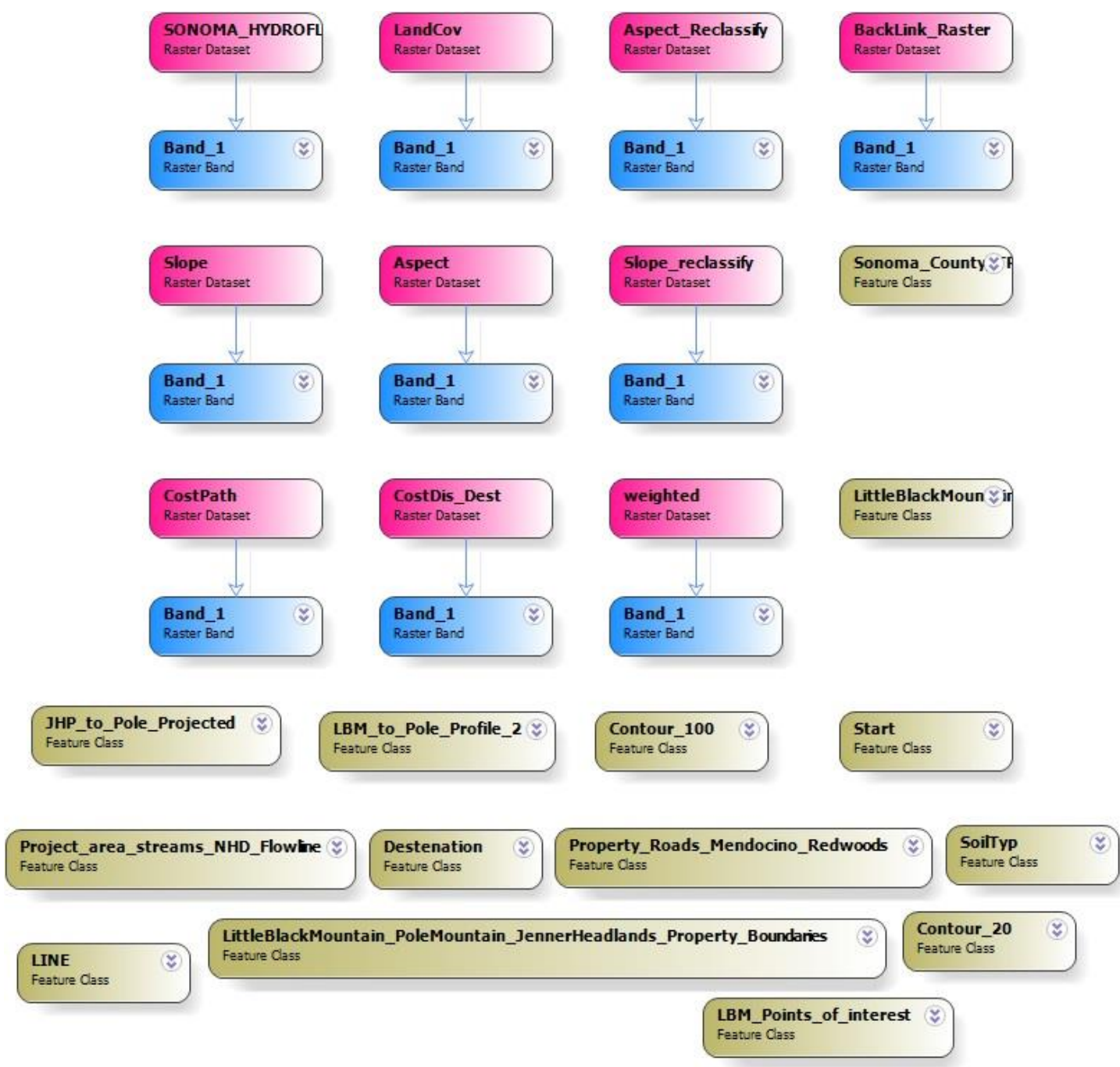

Figure 4-2: The logical data model 
Since all provided project data were not in a file geodatabase format, all the vector data were converted to feature classes while the raster data were converted to raster datasets for storage in the file geodatabase. This enabled the centralization and standardization of the project data to be stored in a common place. Table 4.1 is a breakdown of the project datasets and their descriptions.

Table 4-1: The Logical Data Model

\begin{tabular}{|c|c|c|}
\hline Name & Description & Data Type \\
\hline Contour 100 & Contour 100 feet lines converted from DEM & Feature Class \\
\hline JHP to Pole Projected & $\begin{array}{c}\text { Existing Trail in Jenner Headlands Property } \\
\text { Converted to raster }\end{array}$ & Feature Class \\
\hline Land Cover & Land cover types & Raster Image \\
\hline LBM Points of interest & Points of Interests in Little Black Mountain & Feature Class \\
\hline LBM to Pole Profile & Existing trail in Little Black Mountain & Raster Image \\
\hline $\begin{array}{l}\text { LittleBlackMountain_PoleMount } \\
\text { ain_JennerHeadlands_Property_ } \\
\text { Boundaries }\end{array}$ & The study area & Feature Class \\
\hline $\begin{array}{l}\text { Project area streams NHD } \\
\text { Flowline }\end{array}$ & Existing streams & Feature Class \\
\hline $\begin{array}{c}\text { Property Roads Mendocino } \\
\text { Redwoods }\end{array}$ & Existing road & Feature Class \\
\hline Weighted Cost Distance & $\begin{array}{l}\text { Cost distance output used in the cost path } \\
\text { analysis }\end{array}$ & Raster Image \\
\hline Weighted Backlink & $\begin{array}{l}\text { Cost distance backlink output used in the cost } \\
\text { path analysis }\end{array}$ & Raster Image \\
\hline Proposed Trail & Least cost path output proposing suitable trail & Raster Image \\
\hline Slope & Reclassified slope & Raster Image \\
\hline Soil Type & Soil type used for the analysis & Feature Class \\
\hline
\end{tabular}




\subsection{Data Sources}

The primary source of the project data was the clients themselves. While Shanti Edward from SLT and Brook Edward from TWC organization were the points of contact for the project as a whole, Trevor was the primary contact person for the data. The secondary source of data was the Internet where some datasets like DEM were sourced from. This secondary data were considered since the primary data were not completely sufficient for the project's needs. The DEM was downloaded from a website (Sonoma County Vegetation Mapping and LIDAR, 2016). The soils data used in this project were obtained from Natural Resources Conservation Service (NRCS), which produces the Soil Survey Geographic Database (SSURGO) soil data within the United States Department of Agriculture (United States Department of Agriculture, 2016). The land cover data was downloaded from the Untied States Geological Survey (USGS) particularly from the National Gap Analysis program (GAP) (US Geological Survey, 2016).

\subsection{Data Scrubbing and Loading}

Since this project had multiple sources of data, the data needed to be preprocessed if it were to be usable in the project. Also, the data were not in the same spatial reference. Thus, all the data were projected into California State Plane Zone II FIPS US Feet NAD 83 (EPSG 2226) coordinate system. This was done for two reasons. First, it was a client requirement and therefore had to be implanted. Second, it is the best practice to have all the project data in a common spatial reference. This is to avoid spatial misalignments due to the distortions inherent in different spatial references. When the processing was completed, the data were then transferred into the file geodatabase following the designed database schema.

LittleBlackMountain_PoleMountain_JennerHeadlands_Property_Boundaries was the main layer for this project. Thus, the other layers were all clipped to the spatial extent of this layer. This reduced the storage needs for the data along with making the workflows more efficient and easier, especially with processing during the suitability analysis.

\subsection{Summary}

This chapter discussed the conceptual and logical data models. It explained the data and ground relationships of the project. Additionally, the chapter expounded on the various means used to obtain the data from the different sources. Finally, the chapter illustrated the sources of the data used in this project and how scrubbing and loading of the processed data were done into the file geodatabase. 


\section{Chapter 5 - Implementation}

This chapter discusses the actual process of project implementation as undertaken to reach the goal of the project. It explains how the defined requirements were taken into consideration in building the project output. The implementation is divided into three sections: alternative map, tour map, and the summary of the chapter.

Section 5.1 discusses the data used to implement the project as well as the data type. It also explains the classification of the factors used for the different weighted overly analysis scenarios. Section 5.2 describes all the components used to design the final recreational map project. Section 5.3 provides a brief summary of the chapter.

\subsection{An Alternative Trail}

This section is divided into two sections discussing the data used to implement the project, as well as the suitability analysis method, through weighted overlay analysis and least cost path data.

\subsubsection{Data Reclassification}

The project used raster and vector datasets, all stored in a file geodatabase. The vector datasets, categorized into points, polyline, and polygon, included contours, points of interest, project boundary, roads, streams, and the existing trails. Since all project data provided were not all in a file geodatabase format, all the vector data were converted to feature classes while the raster data were converted to raster datasets for storage in the file geodatabase. 
The raster dataset included DEM, slope, soil type, and land cover. The vector and raster datasets were used as input for the suitability analysis to determine the trail that has been sought for the properties. A DEM was used to derive the required factors including the slope for the suitability analysis as illustrated in Figure 5.1.

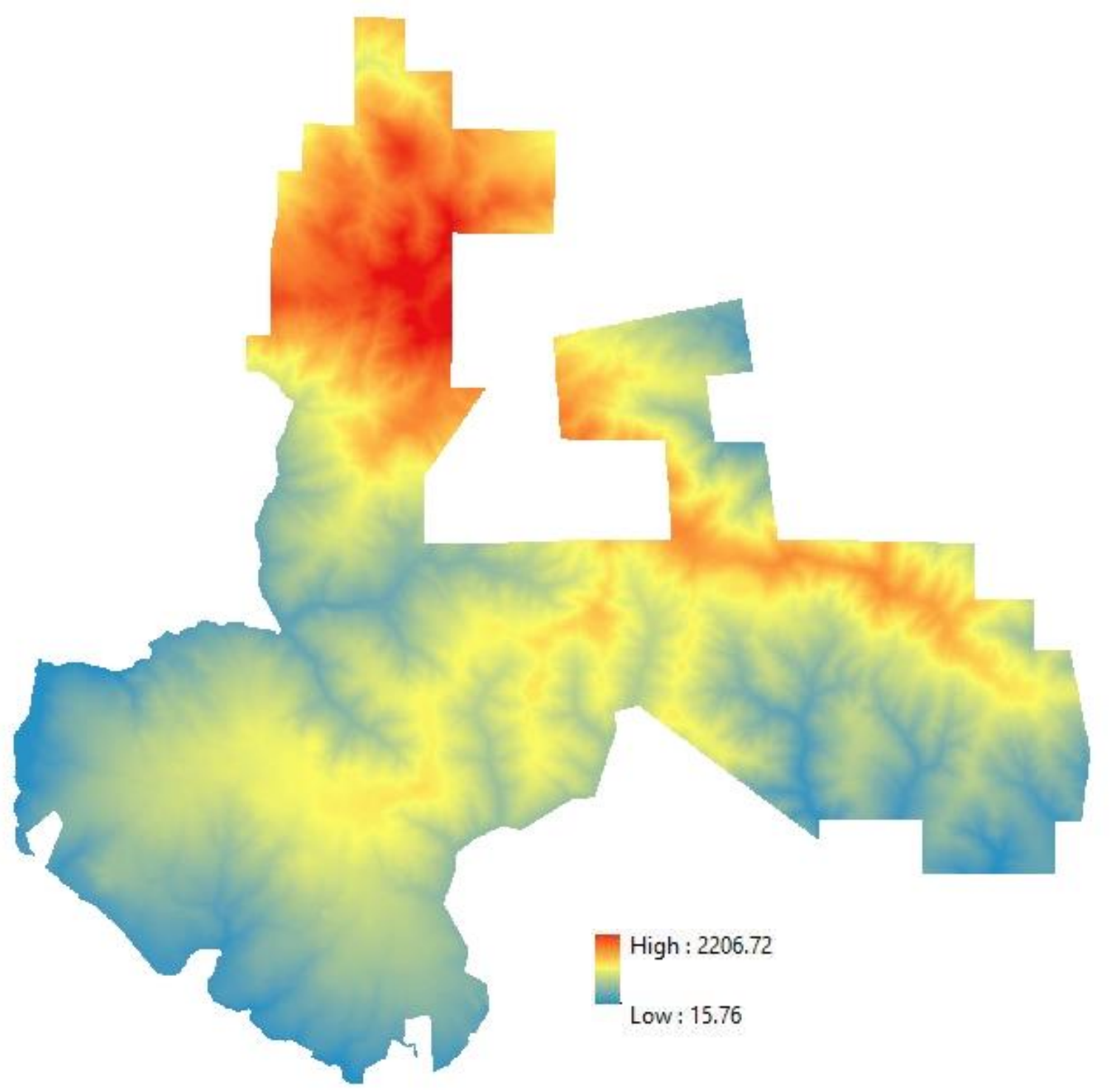

Figure 5-1: DEM Dataset 
The slope was obtained from the 1-meter Hydroflattened Bare Earth DEM, which was then clipped to match the area of interest based on the project boundary. Figure 5-2 illustrates the slope layer used for the project.

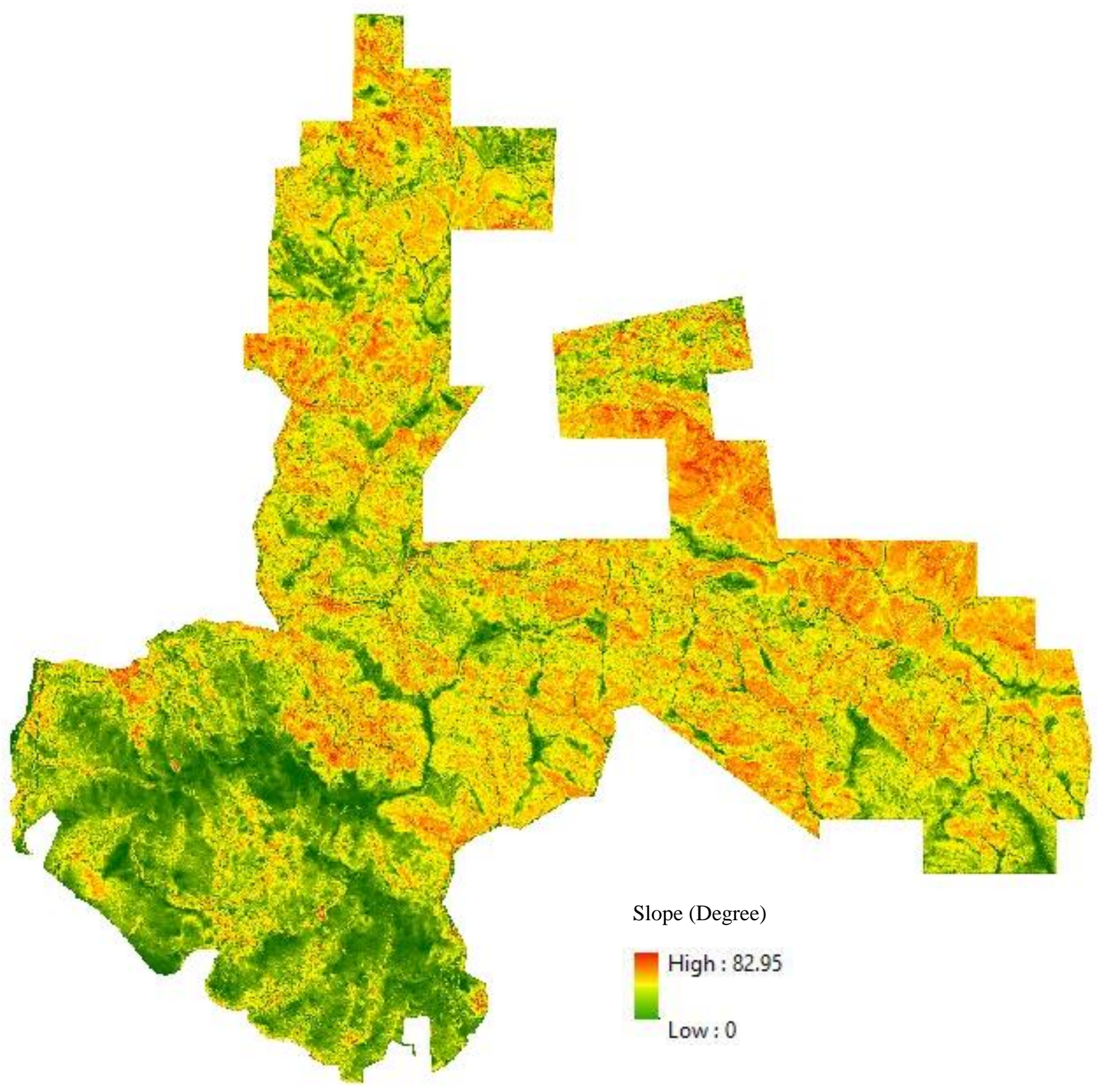

Figure 5-2: Slope Generated from DEM 
Because the slope was the clients' main factor of concern, it was reclassified into five classes: 1 was considered the most suitable for the project while 5 was the least suitable based on literature review as illustrated in Table 5-1 and Figure 5-3.

Table 5-1: Slope Reclassification for the Suitability Analysis

\begin{tabular}{|c|c|}
\hline Slope & Class Value \\
\hline $0-2$ & 1 \\
\hline $2-5$ & 2 \\
\hline $5-10$ & 3 \\
\hline $10-25$ & 4 \\
\hline $25>$ & 5 \\
\hline
\end{tabular}

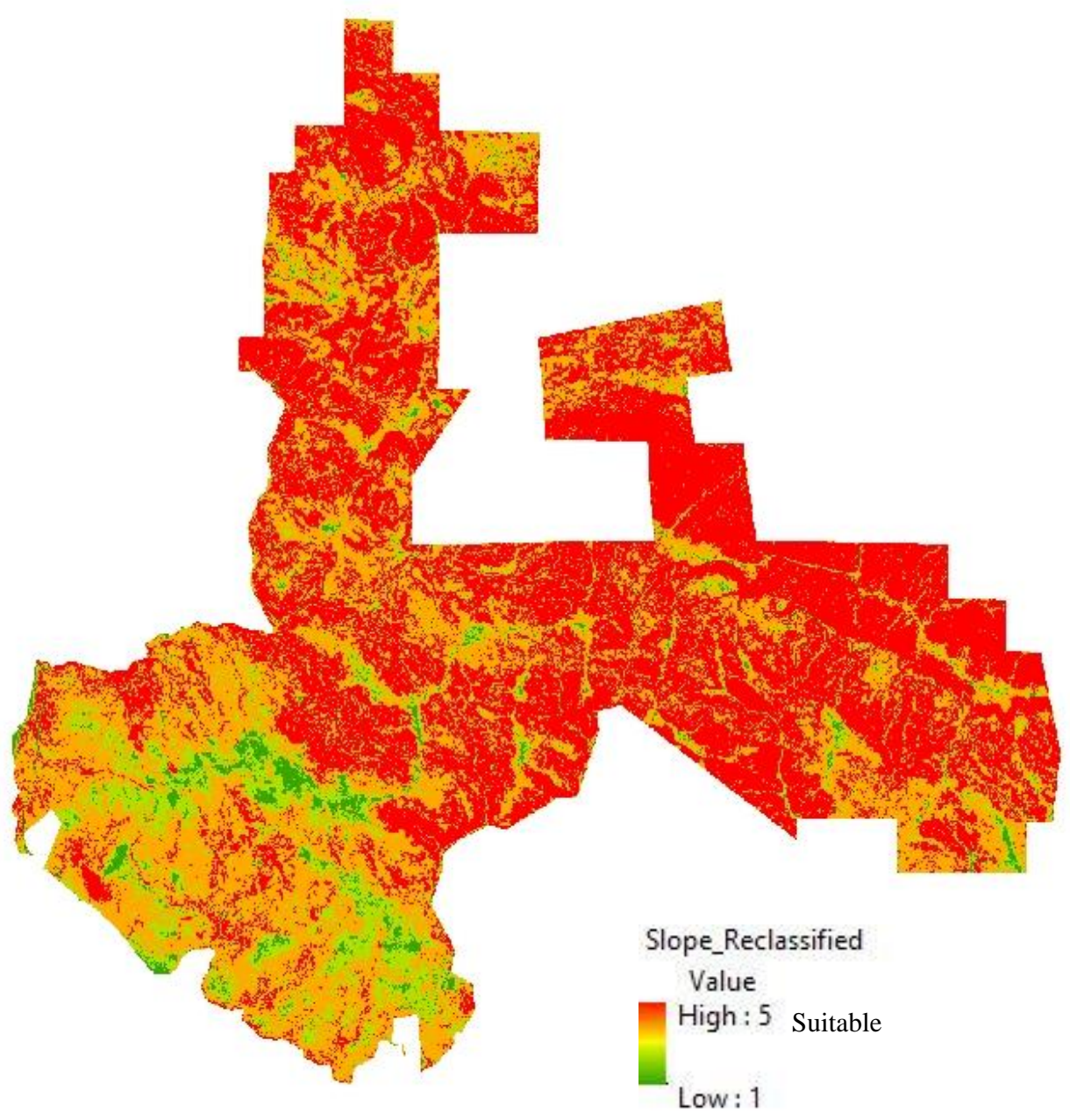

Figure 5-3: The Slope Reclassification 
The soils dataset contained more than 20 soils type within the study area. The data were also clipped to the spatial extent of the project area. The final soil dataset is illustrated in Figure 5-4.

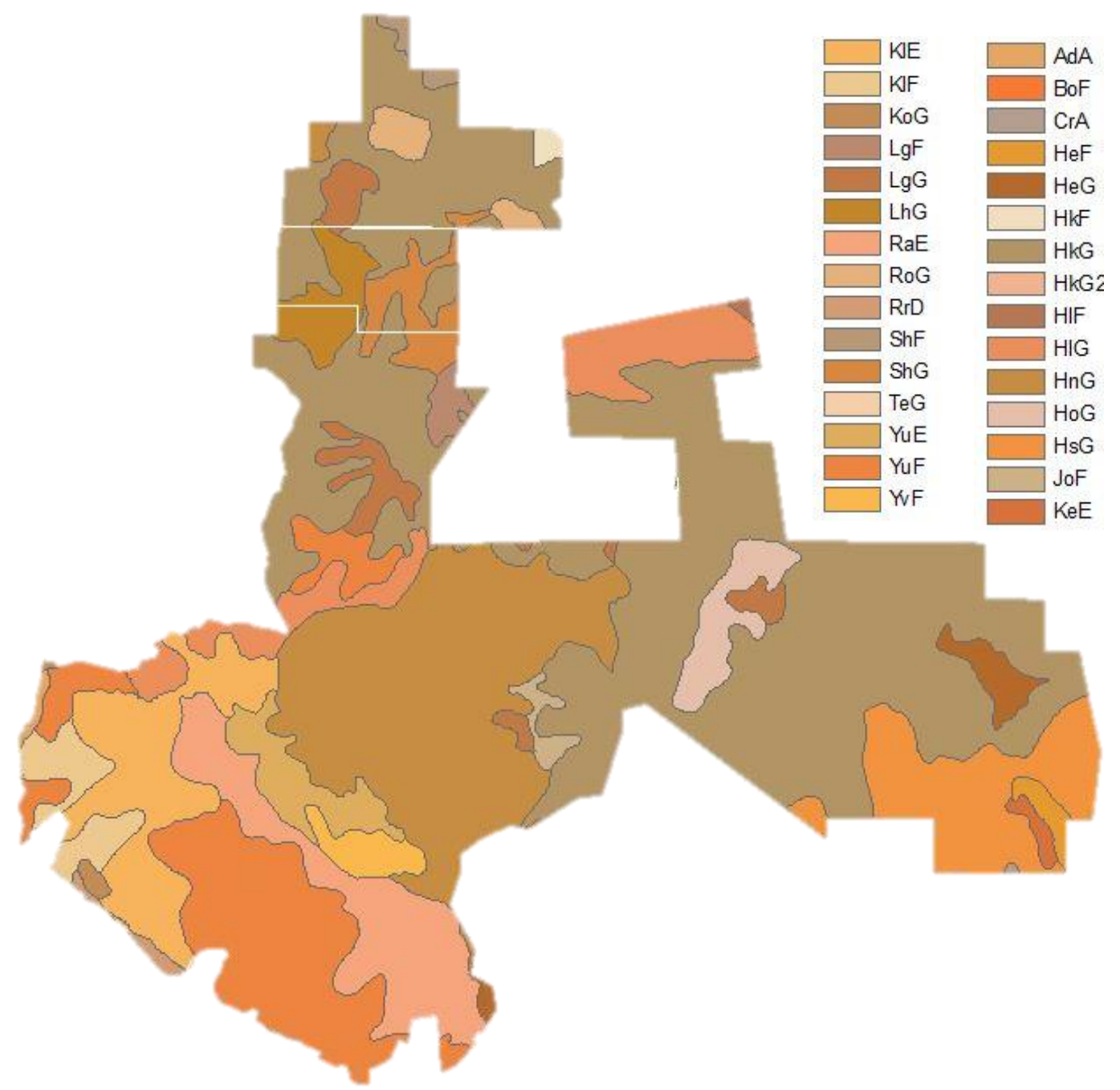

Figure 5-4: Soils Dataset 
The soil type data featured 26 types of soils within the study area. They were reclassified into three classes based on guidelines from Natural Recourses Conservation Service: very limited, somewhat limited, and not limited. The type of very limited indicates that "the soil has one or more features that are unfavorable for the specified use" (United States Department of Agriculture, 2016). The somewhat limited type "indicates that the soil has features that are moderately favorable for the specified use" (United States Department of Agriculture, 2016). The type of not limited "indicates that the soil has features that are very favorable for the specified use." These classifications were used to reclassify the soils type into three main classes numbered 1, 3 and 5, with 1 being "most suitable" and 5 being "least suitable." The reclassification presented in Table 5-2.

Table 5-2: Soil Types Reclassification

\begin{tabular}{|c|c|c|}
\hline Map Unit Symbol & Map Unit Name & Class Value \\
\hline AdA & Alluvial land, sandy & 5 \\
\hline BoF & $\begin{array}{l}\text { Boomer loam, } 30 \text { to } 50 \\
\text { percent slopes }\end{array}$ & 5 \\
\hline $\mathrm{CrA}$ & $\begin{array}{l}\text { Cortina very gravelly sandy } \\
\text { loam, } 0 \text { to } 2 \text { percent slopes }\end{array}$ & 1 \\
\hline $\mathrm{HeF}$ & $\begin{array}{l}\text { Hely silt loam, } 30 \text { to } 50 \\
\text { percent slopes }\end{array}$ & 5 \\
\hline $\mathrm{KeE}$ & $\begin{array}{l}\text { Kidd stonyloam,15 to } \\
\text { 30percent slopes }\end{array}$ & 3 \\
\hline $\mathrm{HkF}$ & $\begin{array}{l}\text { Hugo very gravelly loam, } \\
30 \text { to } 50 \text { percent slopes }\end{array}$ & 5 \\
\hline $\mathrm{HkG}$ & $\begin{array}{l}\text { Hugo very gravelly loam, } \\
50 \text { to } 75 \text { percent slopes }\end{array}$ & 5 \\
\hline $\mathrm{HkG} 2$ & $\begin{array}{l}\text { Hugo very gravelly loam, } \\
50 \text { to } 75 \text { percent slopes, } \\
\text { eroded }\end{array}$ & 5 \\
\hline $\mathrm{HIF}$ & $\begin{array}{l}\text { Hugo-Atwell complex, } 30 \\
\text { to } 50 \text { percent slopes }\end{array}$ & 5 \\
\hline
\end{tabular}


The land cover raster dataset included all the different types of land cover within the study area. This was a very helpful layer that showed all land covers that had been used within the study area and guided the proposed trail through forest and natural vegetation zones and away from areas of human development. The land cover layer is illustrated in Figure 5-5.

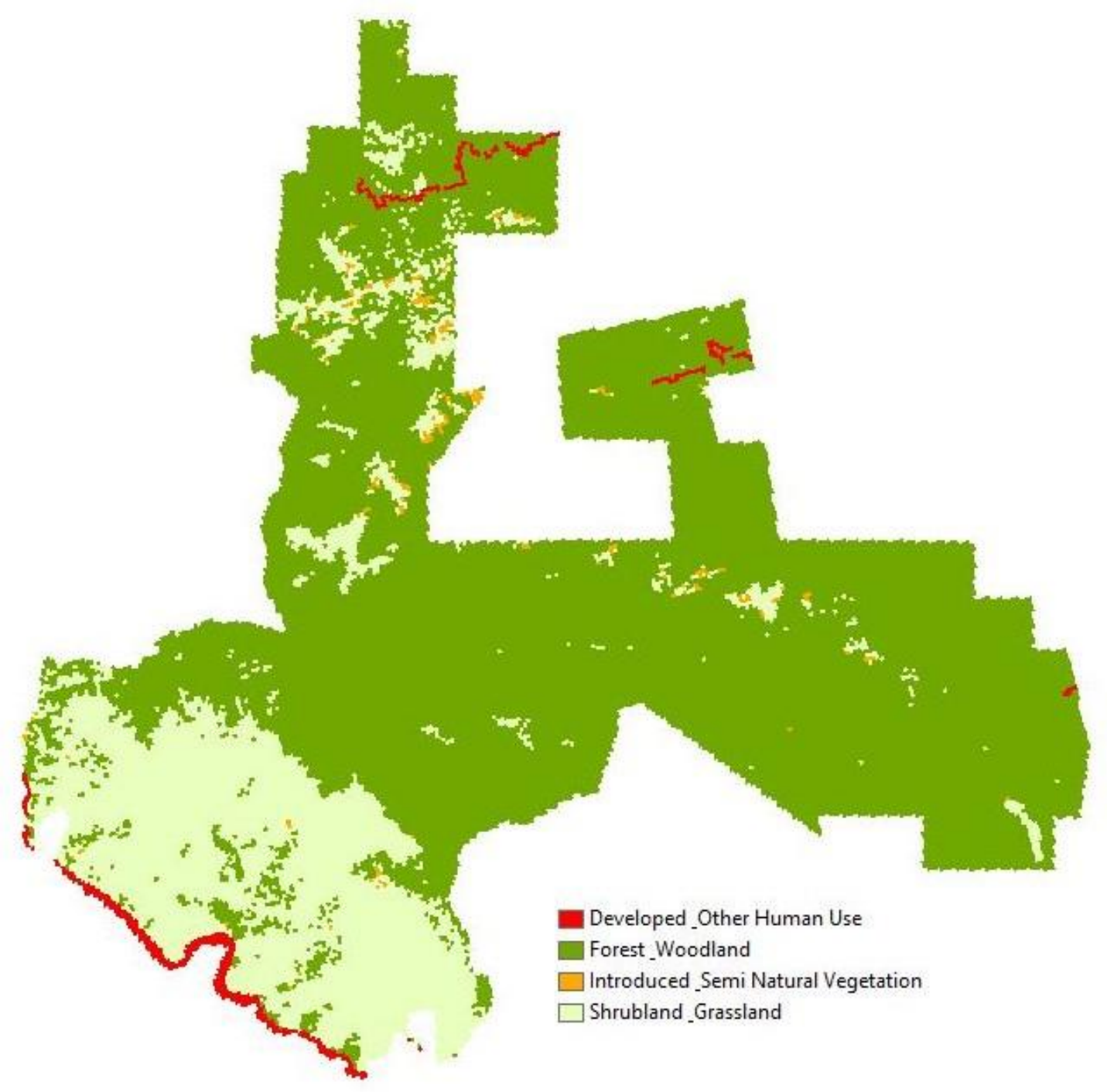

Figure 5-5: Land Cover of SNCPLC 
The land cover dataset was also reclassified for the suitability analysis. For this dataset, the human developed areas were considered the most unsuitable while the forest and woodland land cover types were considered the most suitable for the recreation trail. Therefore, the Land cover was reclassified to put the area of forest as 1 (most suitable) and human development as 4 (least suitable). The reclassification of land cover is illustrated in both Table 5-3 and Figure 5-6.

\section{Table 5-3: Land Cover Reclassification}

\begin{tabular}{|c|c|}
\hline Land cover type & Class value \\
\hline Forest \& Woodland & 1 \\
\hline Shrubland \& Grassland & 2 \\
\hline Introduced \& Semi Natural & 3 \\
\hline Developed \& Other Human Use & 5 \\
\hline
\end{tabular}

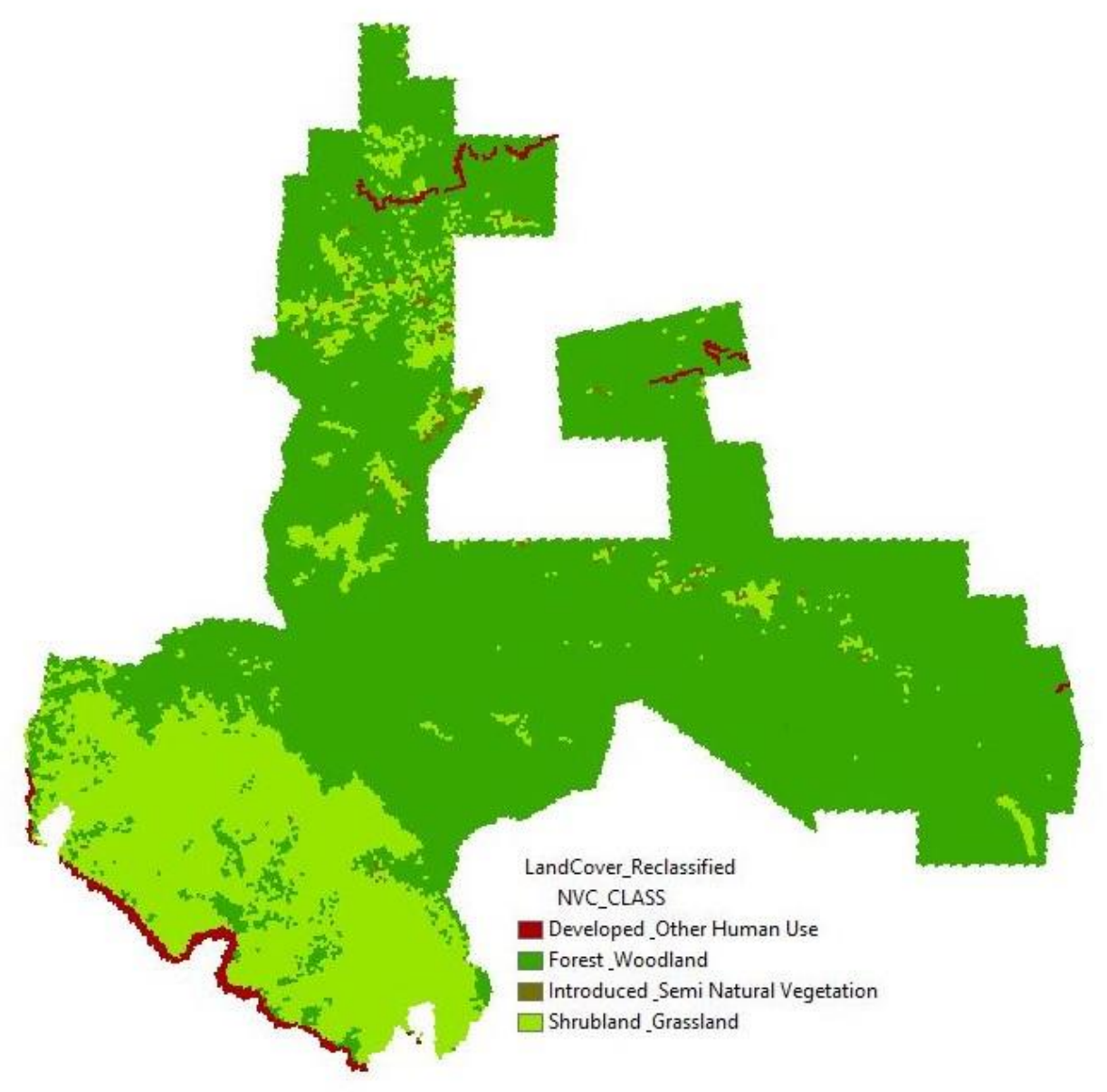

Figure 5-6: The Reclassification of the Land Cover 


\subsubsection{Suitability analysis method}

After all factors and scenarios were identified and agreed upon with the stakeholders, the suitability analysis was performed using both weighted overly analysis and least cost path methods. To perform the suitability analysis, all three input factors (Slope, Soil Type, and Land Cover) were reclassified and weighted differently to produce the most suitable zone for recreational trail.

After each dataset was prepared and reclassified, the weighted overlay analysis was carried out to determine the suitable zones for the trail. All factors were weighted differently based on the clients' advice. The slope was weighted $60 \%$ of influence and both soil type and land cover were weighted $20 \%$ of influence. The output of the weighted overly analysis ranged from 1 to 5 as illustrated in Figure 5-7.

\begin{tabular}{|c|c|c|c|c|c|}
\hline Raster & So Influence & Field & Scale Value & \multirow[t]{2}{*}{$\wedge$} & 4 \\
\hline ᄉ LandCover_Reclas & 20 & Value & k & & \\
\hline & & 1 & 1 & & \\
\hline & & 2 & 2 & & $x$ \\
\hline & & 3 & 3 & & \\
\hline & & 5 & 5 & & 수 \\
\hline & & NODATA & NODATA & & \\
\hline$\hat{\lambda}$ Soiltype_Reclassi & 20 & Value & 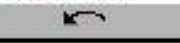 & & $\downarrow$ \\
\hline & & 1 & 5 & & \\
\hline & & 2 & 3 & & \\
\hline & & 3 & 2 & & \\
\hline & & 5 & 5 & & \\
\hline & & NODATA & NODATA & & \\
\hline ᄉ Slope_Reclassified & 60 & Value & W & & \\
\hline & & 1 & 1 & & \\
\hline & & 2 & 2 & & \\
\hline & & 3 & 3 & & \multirow{2}{*}{ है } \\
\hline & & 4 & 4 & & \\
\hline & & 5 & 5 & & \\
\hline & & NODATA & NODATA & $\checkmark$ & 些 \\
\hline Sum of influence & 100 & & Influence & & \\
\hline Evaluation scale & & From & By & & \\
\hline 1 to 5 by 1 & $\checkmark$ & & & & \\
\hline
\end{tabular}

Figure 5-7: The Influence Percentage for the Factors 
The result of the weighted overlay analysis was a map of suitability produced from the suitability analysis, as illustrated in Figure 5-8.

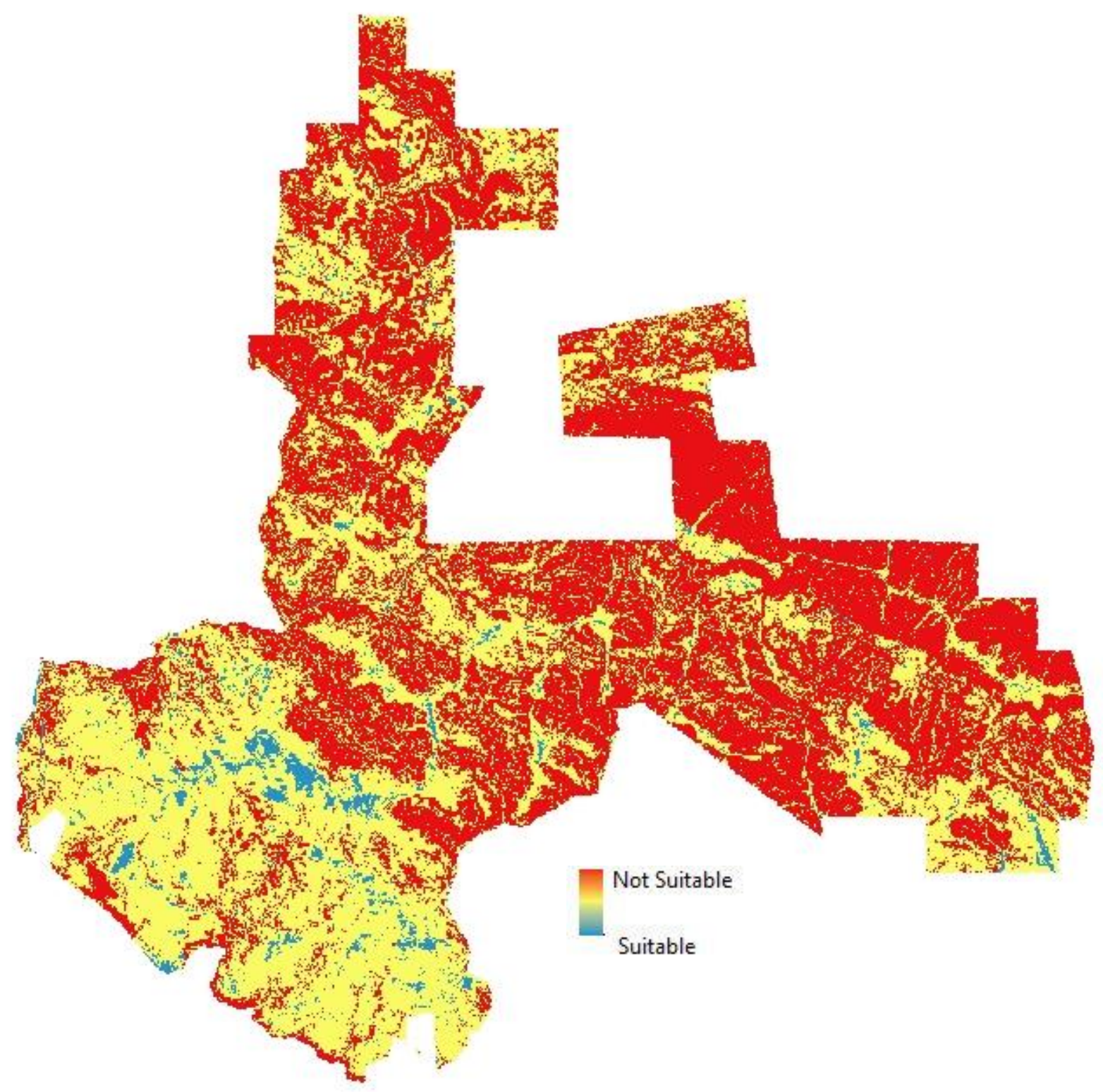

Figure 5-8: The Suitability Produced from Weighted Analysis 


\subsubsection{Proposed Trail}

The existing trail dataset was included in the analysis as new factor, because reconstructing the old trail would be affordable alternative to constructing a new trail. The existing trail was converted to raster after having been buffered 100 feet and named Buffer_existing_trail. The existing trail was given a value of one meaning no extra cost, and the rest of the dataset was given a value of five, meaning extra cost as illustrated in Figure 5-9.

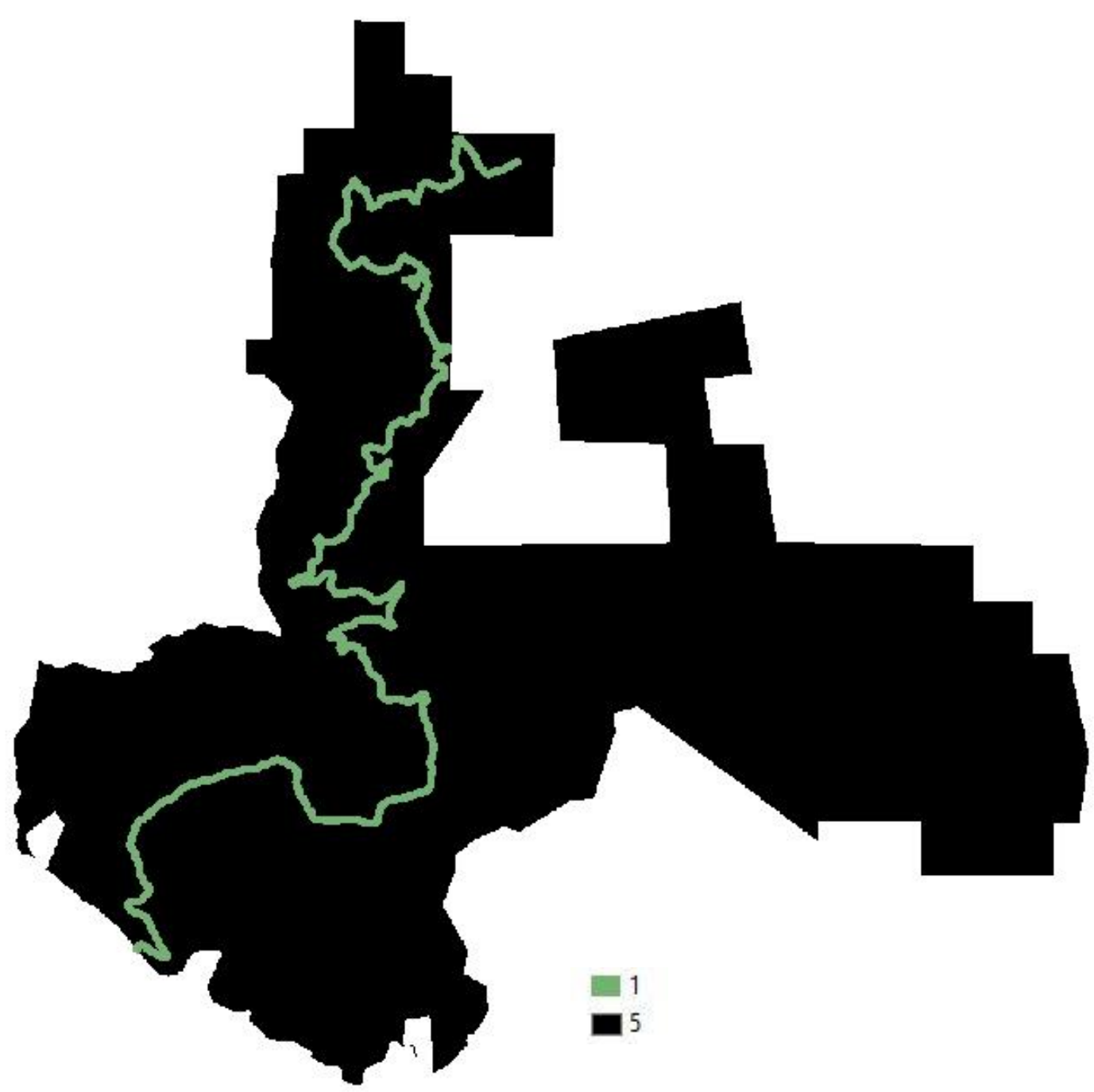

Figure 5-9: The Existing Trail Dataset 
As the first step in least cost path analysis, the suitability surface was used as the cost surface and the least total cost distance for each cell in the map from the feature point of interest was calculated. To get the cost distance of the study area a map algebra expression was used in the Raster Calculator tool to calculate the cost surface. The expression used to calculate the cost surface was structured to include $25 \%$ of the existing trail as a factor. The expression used to calculate the cost surface is illustrated in Figure 5-10.

(Slope_Reclassified $* 0.6+$ SoilType_Reclassified $* 0.2+$ LandCover_Reclassified $* 0.2)$

+ Buffer_existing_trail $* 0.25$

Figure 5-10: Calculating the Cost Surface Considering the Existing Trail

Slope was weighted $60 \%$ because it had the most influence in the study area and showed the elevation of the sustainable trail location. Both soil type and land cover were weighted $20 \%$ because they had the lower influence. The existing trail dataset was then multiplied by $25 \%$ in the interest of cost efficiency in reconstructing the new trail. Cost path analysis was then run to determine the least cost path from the feature of interest to a destination. The last step of the analysis was converting the output of the least cost path from a raster to a polyline feature. 


\subsection{Tour Map}

This section illustrates all the components that were used to design and create the final maps. These final maps included the alternative trail and different basemap.

The clients' logos were among the earliest elements provided to be in the final products. After performing the suitability analysis and producing the proposed trail, an elevation profile was generated from the 1-meter Hydroflattened Bare Earth DEM by using Elevation profile tool downloaded from (esri) as illustrated in Figure 5-11.

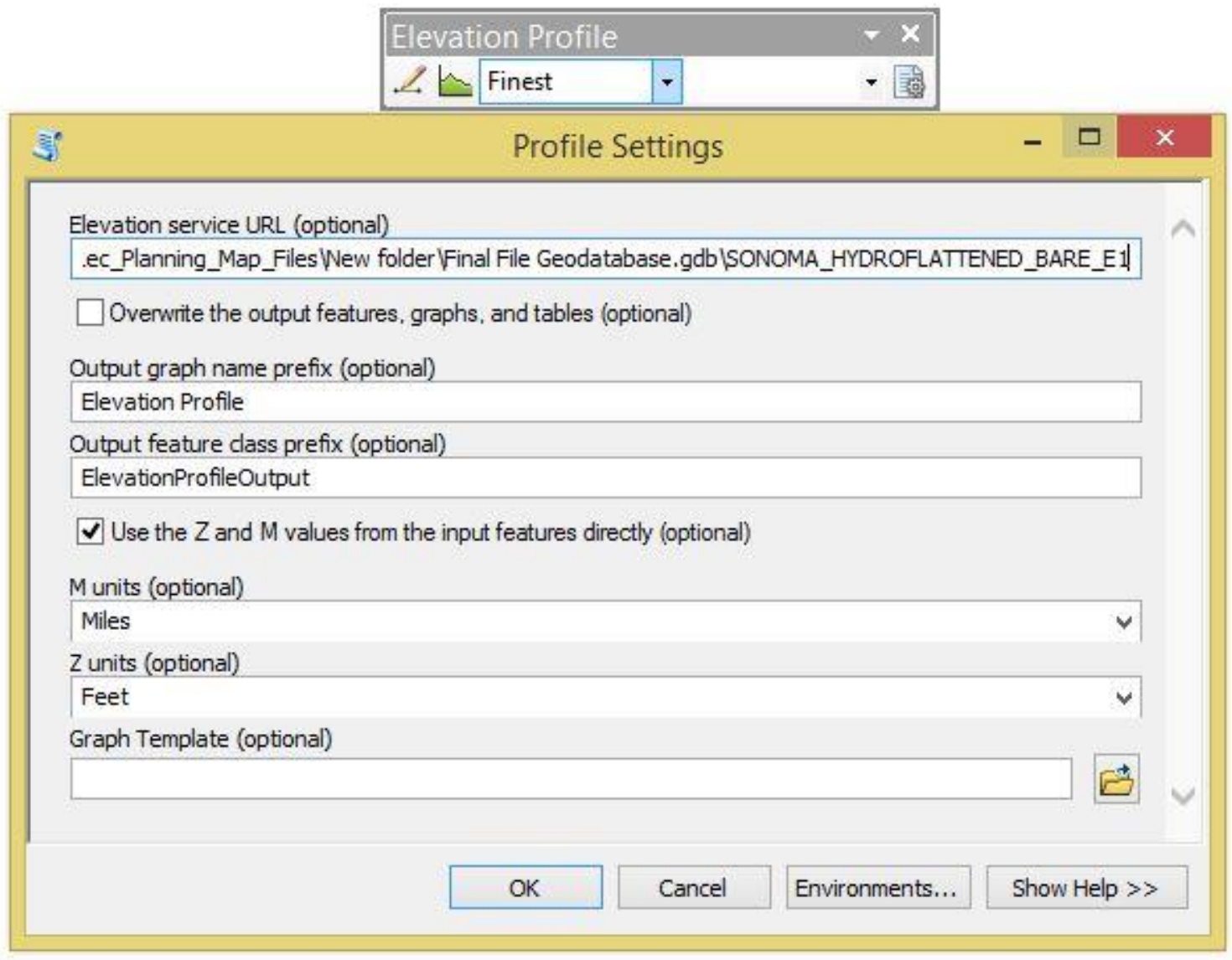

Figure 5-11: The Elevation Profile Tool 
This tool was used to generate an elevation profile and mileage by simply selecting the proposed line produced from output of the suitability analysis. As an example, an elevation profile was created for Little Black Mountain in feet and the distance in miles as illustrated in Figure 5-12.

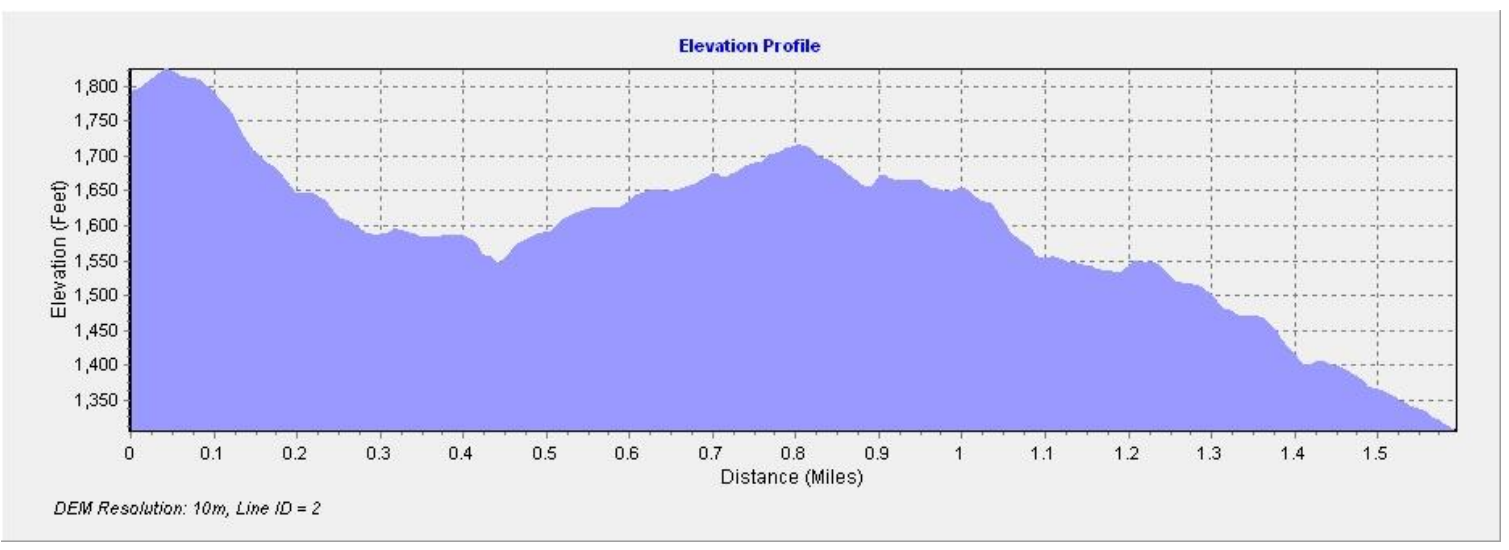

Figure 5-12: An example of A profile in Little Black Mountain

Additional components were used in the final maps, including: legend, scale, north arrow, and the title of the map. Additionally, two base maps were used in the final product. The first map was designed by using an aerial image basemap with the alternative trail highlighted. The other map used contour lines as the background. 
A contours dataset was a derived product. This dataset was derived from the project DEM with an elevation interval of 100 feet. The contour lines, in feet, were used in the final product map and are illustrated in Figure 5-13.

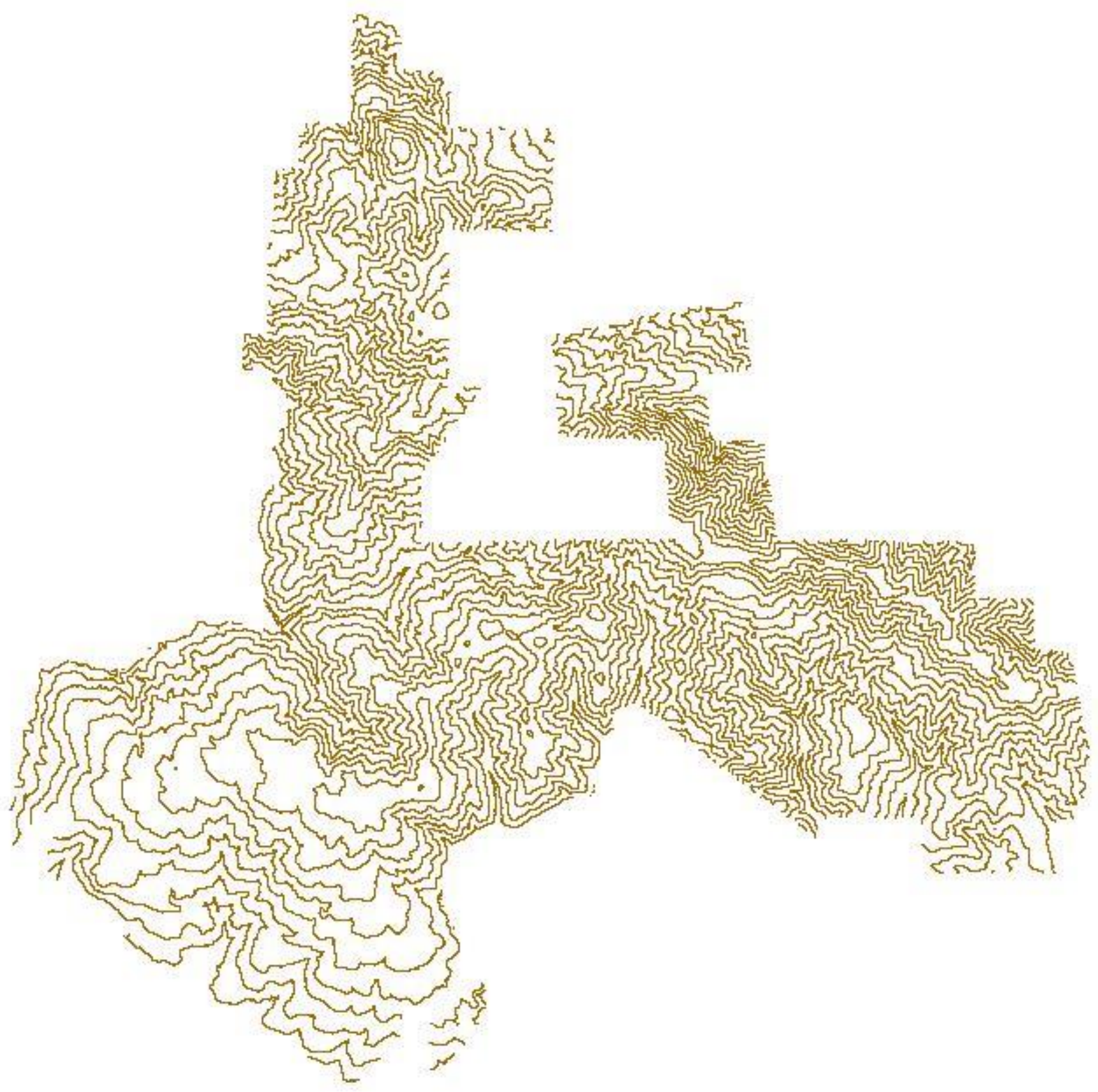

Figure 5-13: Contours with on Interval of 100 Feet 
Aerial imagery was obtained from the Sonoma Vegetation Mapping and LiDAR Program (Sonoma County Vegetation Mapping and LIDAR, 2016). These images were used as a base map for the existing trail to show the path within the study area as illustrated in Figure 5-14.

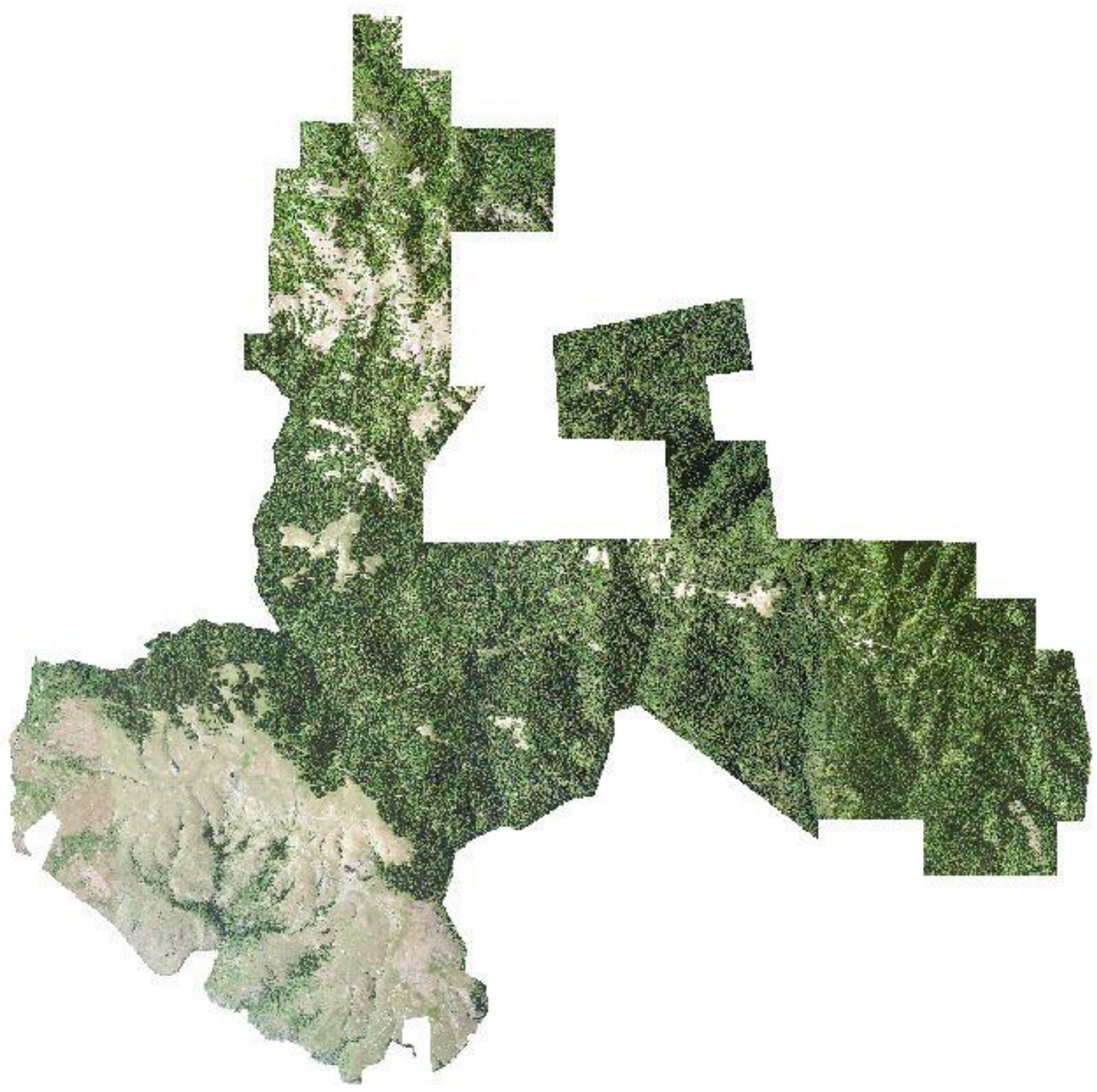

Figure 5-14: Aerial Imagery 


\subsection{Summary}

This chapter discussed the implementation procedures involved in developing the recreational trail. It explained, in detail, the tasks and phases for the project plan. The suitability analysis technique was the primary method of developing the recreational trail after receiving all the data needed in this project. Weighted overlay analysis and least cost path methods were implemented as part of the suitability analysis and were illustrated in detail in this chapter. Additionally, the chapter discussed all the elements used in the final map products. 


\section{Chapter 6 - Results and Analysis}

This project was undertaken to develop a recreational trail for the Sonoma North Coast Protected Land Complex (SNCPLC) property. To develop this trail, several scenarios were applied in a suitability analysis. This analysis factored in different components (slope, soil type and land cover), which were weighted differently to evaluate the best zones for the recreational trail. This chapter is comprised of a discussion of the analysis conducted and the final results of this analysis. Section 6.1 illustrates the suitable zones after applying the weighted overlay analysis, as well as the least cost path analysis as applied between two points in the SNCPLC. Section 6.2 is a discussion of the final maps' design, which includes the proposed trail and the existing trail. Section 6.3 is a brief summary of the chapter.

\subsection{Proposed Trail within the Suitable Zones}

The weighted overlay analysis provided a means of identifying the most suitable and non-suitable areas for recreational trails in the SNCPLC. The optimal area for the trail would feature lower slopes, areas within grassland or forest land cover, and areas whose soil types are contain (very gravelly and sandy), terrace escarpments, and rock land. The recreational trail developed as a result of this analysis was drawn as a map to represent the recreational trail within the SNCPLC.

After applying different weights to the different factors considered in the weighted overlay analysis, the suitable areas were identified. Figure 6-1 illustrates the result of the weighted overlay analysis. The most suitable zones are represented as light color, while the dark color was used to represent the non-suitable zones. Most of the areas in the south of the SNCPLC are very suitable zones because they are areas with lower slope and most of these areas are covered by grass land. 


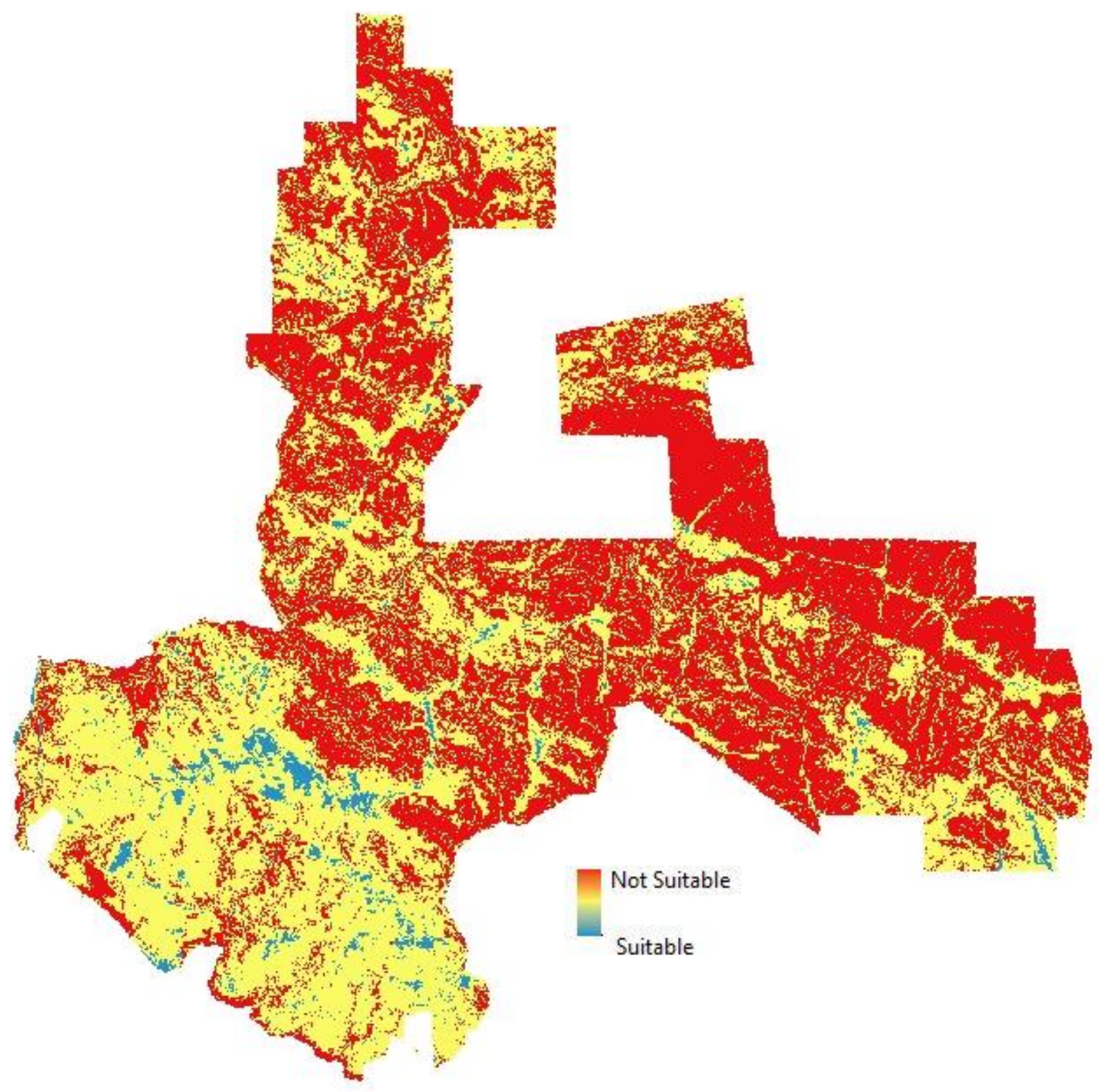

Figure 6-1: The Suitable and Non-Suitable Zones 
The clients were interested in a view of the SNCPLC overlaid on an aerial imagery. A one meter resolution aerial image was used to fulfil this requirement that would enable the SLT and TWC staff to view the property with an imagery overlaid. This not only helped both clients see the existing trail of the SNCPLC, but also aided them in managing and locating the points of interest. The result is illustrated in Figure 6-2.

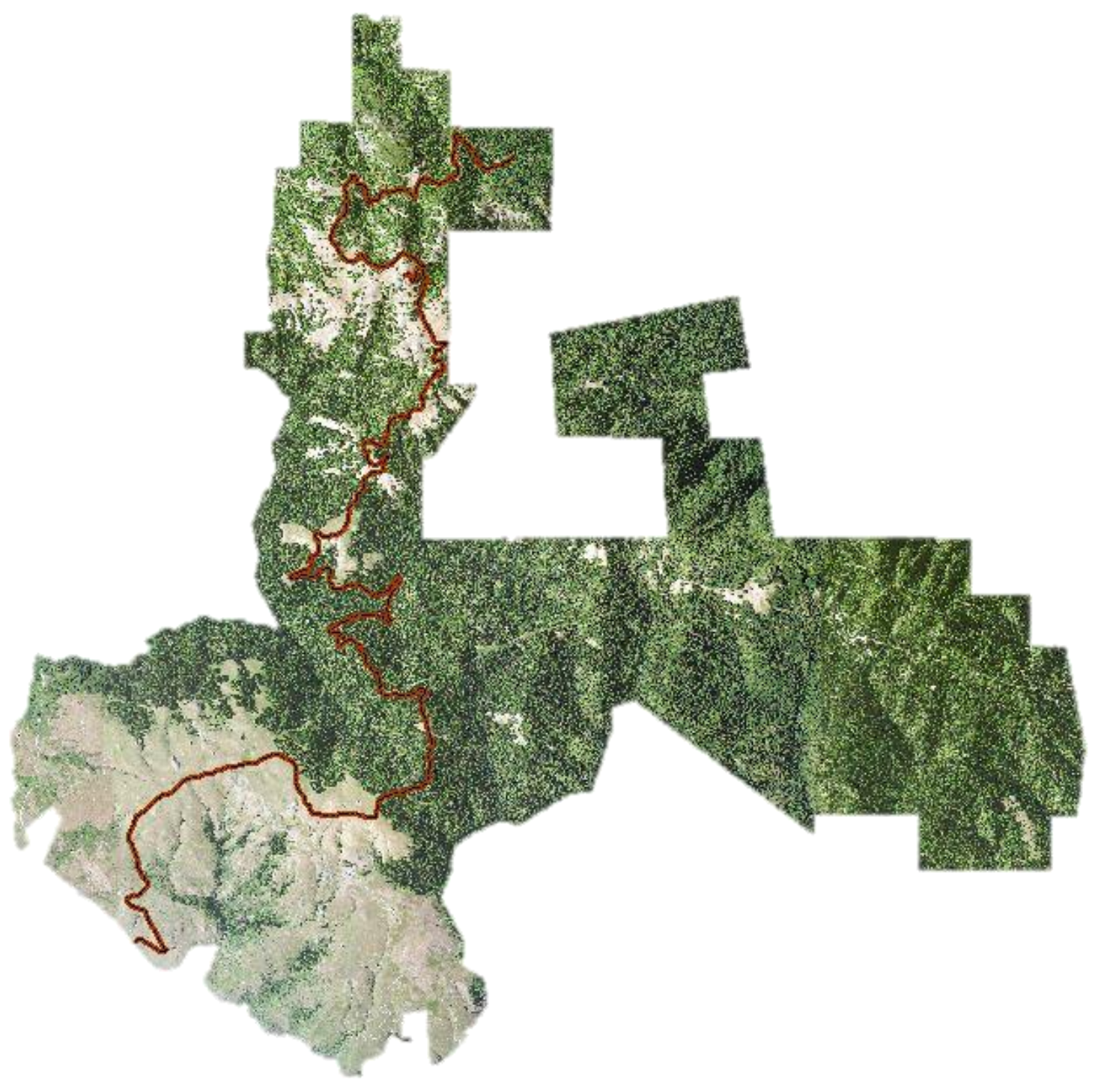

Figure 6-2: The Existing Trail on An Aerial Image of SNCPLC 
Figure 6-3 present the proposed recreational trail which consider the input of the exiting trail.

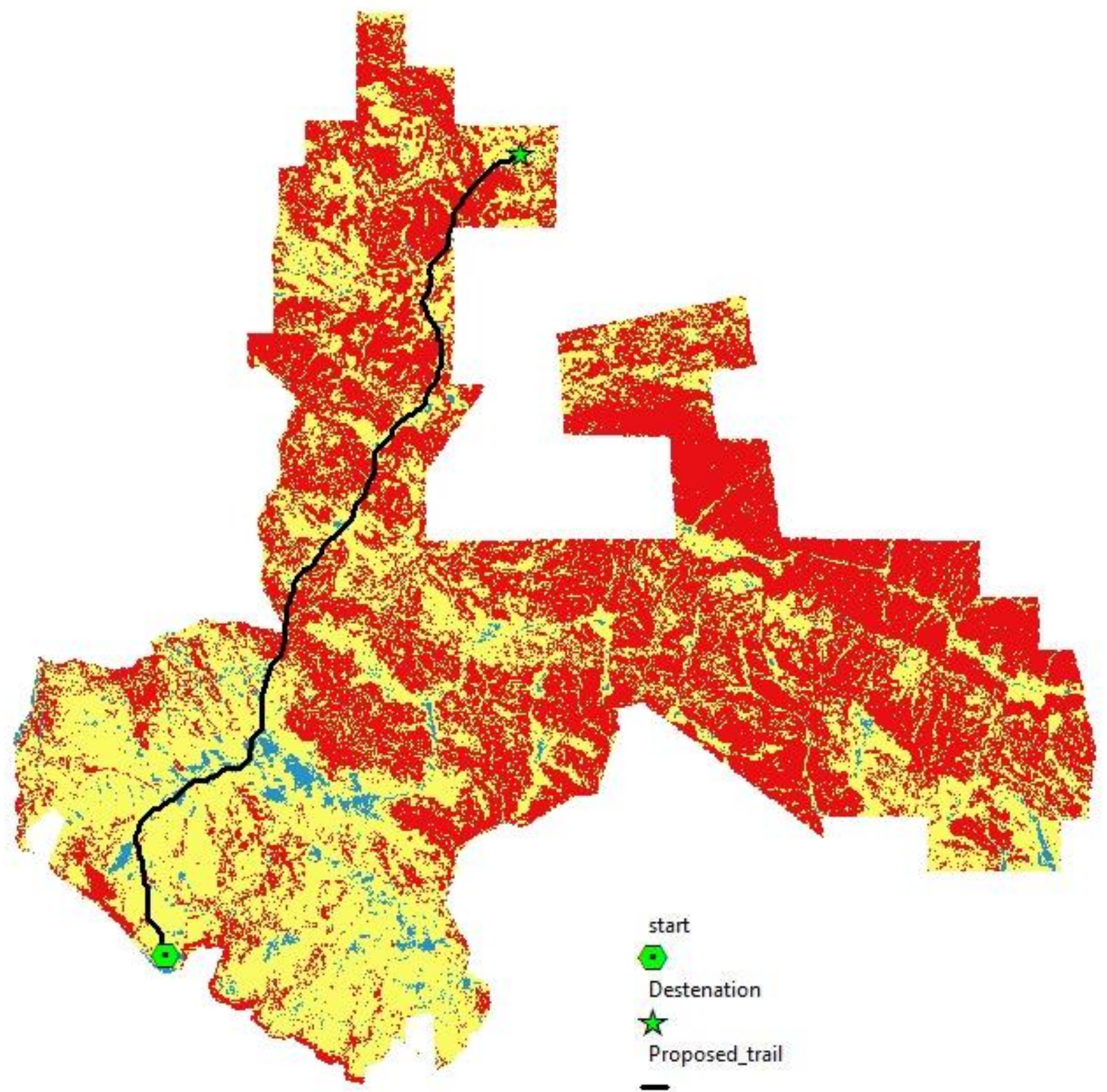

Figure 6-3: The Proposed Trail 
This map could help the management of SLT and TWC in reconstructing the developed recreational trail location within the existing trail. This is illustrated in Figure 6-4.

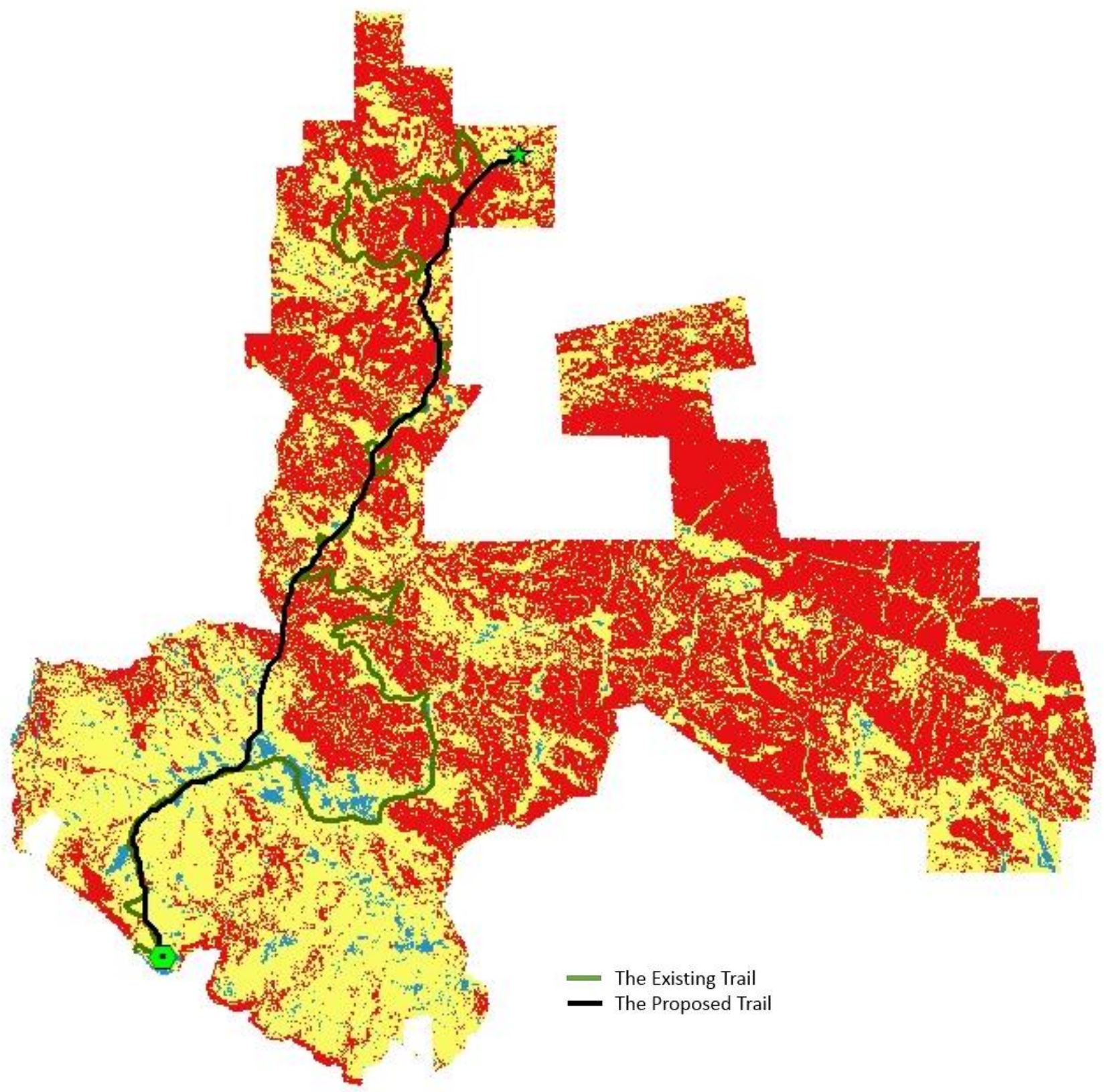

Figure 6-4: The Existing and the Proposed Trails 


\subsection{Final Map Design}

These final maps represent the proposed trail with two different base maps. They show the elevation profiles as graphic images. Moreover, they include the mileage for the proposed trail. Figure 6-5 shows the first proposed trail.

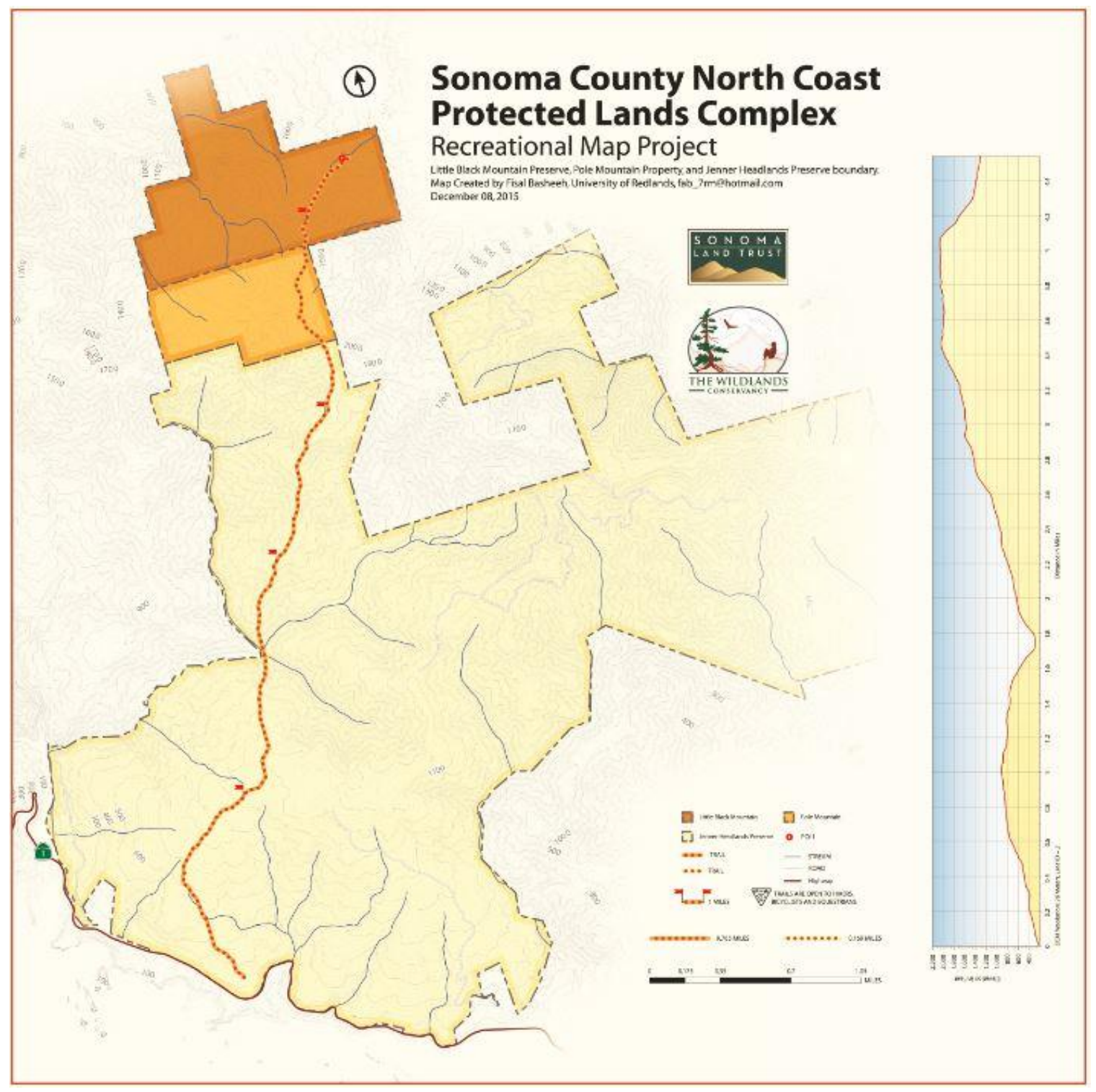

Figure 6-5: The Proposed Trail Map 
Figure 6-6 shows the same proposed trail but uses a different base map. This base map is aerial imagery, and elevation data was sourced from the Sonoma Vegetation Mapping and LiDAR Program (Sonoma County Vegetation Mapping and LIDAR, 2016).

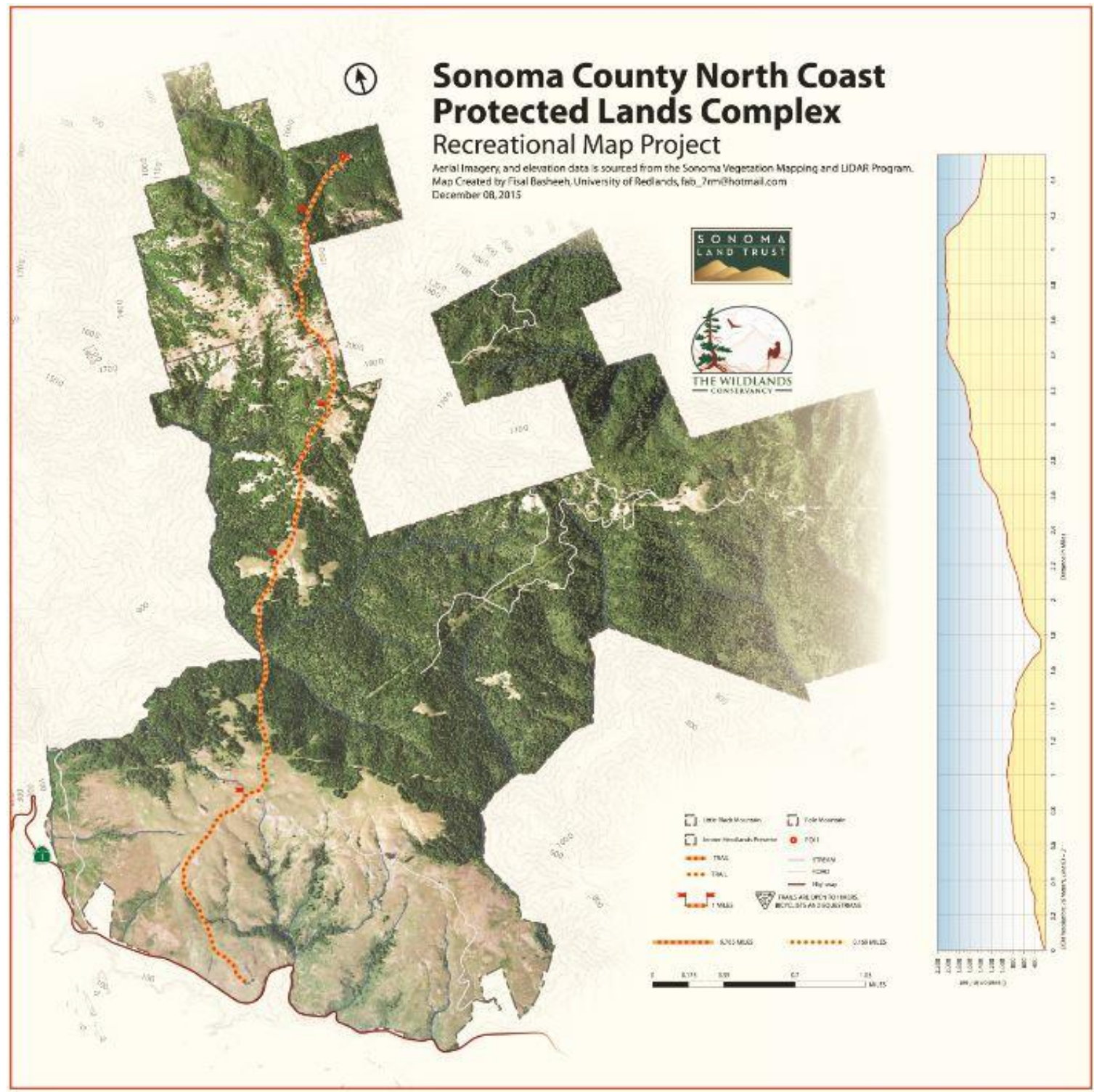

Figure 6-6: The Proposed Trail on An imagery Basemap 
Figure 6-7 shows the existing trail uses an imagery as base map. This base map is aerial imagery, and elevation data was sourced from the Sonoma Vegetation Mapping and LiDAR Program (Sonoma County Vegetation Mapping and LIDAR, 2016).

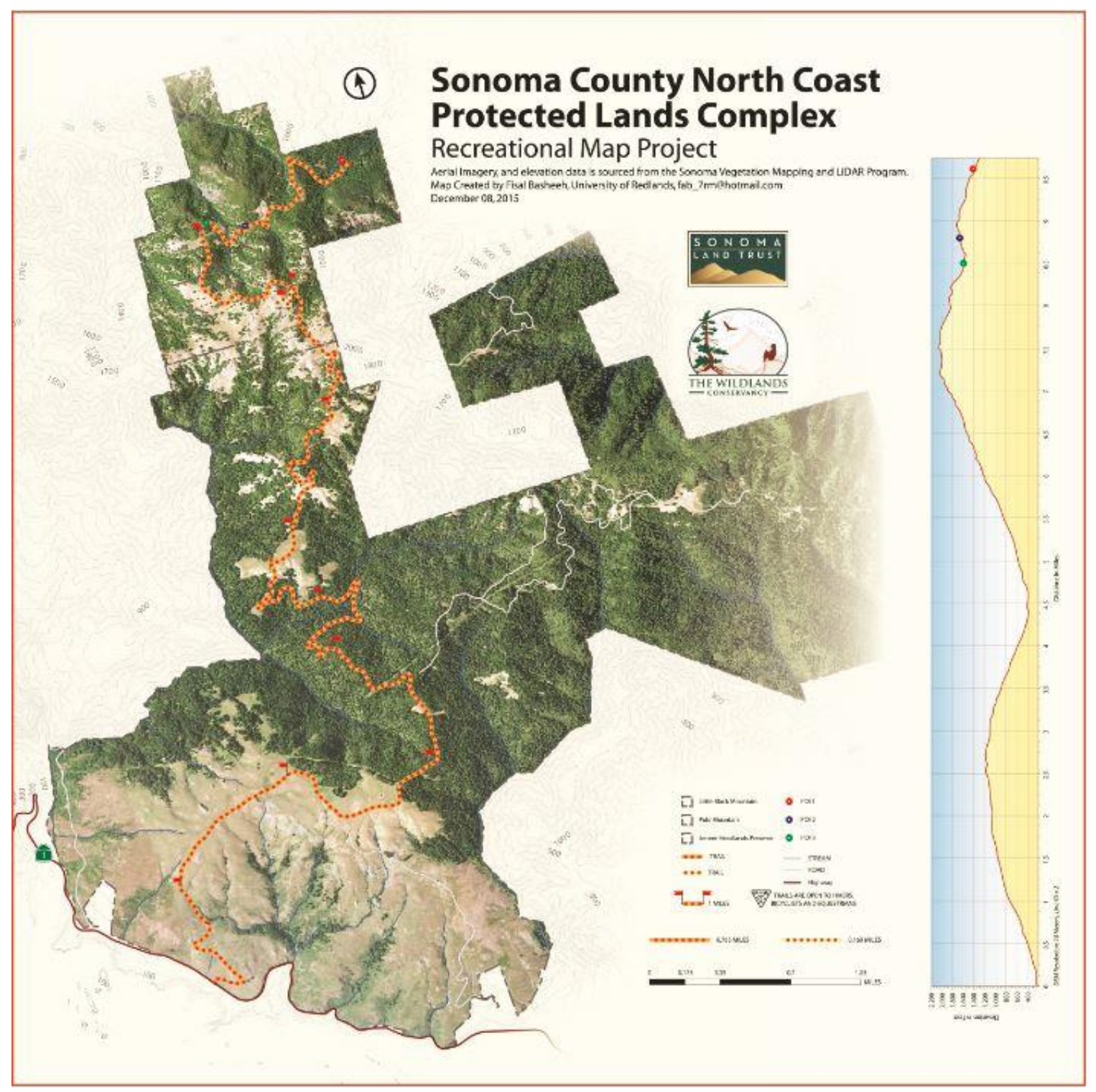

Figure 6-7: The Existing Trail on An imagery Basemap 


\subsection{Summary}

Chapter 6 discussed and highlighted the final results of the project. This chapter was focused on identifying the suitable areas for developing a recreational trail for the SNCPLC. According to the clients, the most suitable areas for the recreational trail would be areas under low gradient slopes and covered by grasslands or forests. Based on the soil type, the optimal areas were comprised of under 26 of soil types. Cost distances were derived using weighted overlay analysis and raster calculator. These surfaces were then used to determine trails. There was a minimal influence of the existing trail based on a $25 \%$ influence factor in the analysis. The resulting recreational trail was highlighted in two maps: one with aerial imagery and one with administrative boundaries basemap. These maps will be used for planning purposes and will help both SLT and TWC members become more knowledgeable about the properties and the points of interests. 


\section{Chapter 7 - Conclusions and Future Work}

A recreational map was needed to facilitate planning efforts in Sonoma North Coast Protected Land Complex (SNCPLC) between the Sonoma Land Trust properties (Little Black Mountain Preserve and Jenner Headlands Preserve) and The Wildlands Conservancy's property (Pole Mountain property). This project was implemented to develop recreational trail maps for SNCPLC. Applying geographic information systems (GIS) helped the staff and other stakeholders to better understand the changes occurring and to better manage the properties.

GIS techniques offered unique options for suitability analysis as it provided a platform to overlay landscape layers in a weighted approach for optimal trails and landscape analysis. Also, the least cost path was used to identify the path within the suitable zones as part of the suitability analysis. This suitability analysis was performed using the tools available within the ArcGIS for Desktop 10.3. The major factors considered in the suitability analysis were slope, soil type, and land cover. Various maps were created to highlight these factors within the SNCPLC. The analysis results were represented in a map highlighting the identified trail within the SNPCLC Complex.

Both SLT and TWC members were concerned about the elevation profile and the length of the recreational trail. This project encompassed creation of the elevation profile and mileage computations for the recreational trail developed, both of which were included in the final map products as graphic images for ease accessibility for map userAs the project continues to progress, it would behoove both SLT and TWC members to keep working in GIS for the SNCPLC in land management. This will also ensure that the data is updated for any future projects. Presently, there are three recommendations for the project in the future. First, field survey data must be collected, especially for the proposed trail location. This survey would be more efficient in terms of the proposed trail within the affordable and likely zones. It would also help to observe the zones of the developed recreational trail within the consideration factors such as slope, soil type, and land cover. Additionally, this field data survey will be a premium factor to consider in applying the weighted overlay analysis.

Second, incorporating the ArcGIS desktop results into ArcGIS online would enable consumption by a large and diverse audience. This can be developed as a three dimensional (3D) map which shows the elevation for the trail in 3D. Additionally, it can be browsed from any device, anywhere. It would also be more beneficial as an interactive web map that allows for more layers to be added in the future as they become available. This would make it easier for the SLT and TWC staff and stakeholders to update the information for the management of the SNCPLC.

Lastly, increasing the environmental factors would help the members in developing the recreational trail for a diverse user group. Examples of the factors that can be incorporated include soil erosion, rainfall, number of users, and forest type. Both soil erosion and rain are powerful factors that would affect the path over time. 


\section{Works Cited}

Abushnaf, F. F., K. J. Spence, and I. D. Rotherham (2013). Developing a Land Evaluation Model for the Benghazi Region. Retrieved from Developing a Land Evaluation Model for the Benghazi Region: http://ac.elscdn.com/S2212670813000146/1-s2.0-S2212670813000146main.pdf?_tid=b47bbb7a-7c09-11e5-bf5e00000aab0f6b\&acdnat $=1445881862 \_6 d c 97 a 73 c 4 b 2 c 28 d 6 a 10903 c 83 b 97 c 90$

esri, ArcGIS online. GeoPlanner for ArcGIS. Retrieved from ArcGIS: https://doc.arcgis.com/en/geoplanner/documentation/find-the-best-place-usingweighted-overlay.htm

esri, ArcGIS Resource Center. ArcGIS Resource Center, Help. Retrieved from ArcGIS Resource Center : http://help.arcgis.com/EN/ARCGISDESKTOP/10.0/HELP/index.html\#//009z000 000s1000000.htm

Billings, M. (1847). The frick in early 19th century industrial planning. In M. Billings, \& I. Overbill (Ed.), What the frick? Frick implementions after the Age of Reason (pp. 45-78). Fargo, ND, USA: Decoder Publishing.

esri (2014). ArcGIS Resources. Retrieved from ArcGIS Resources: http://blogs.esri.com/esri/arcgis/2014/05/20/elevation-profile-toolbar-add-in-isavailable-for-download/

Futrell, M., and M. LaRoche (2015). GIS and GPS for Recreational Trail Planning. Retrieved from GIS and GPS for Recreational Trail Planning: http://www.dcr.virginia.gov/recreational-planning/document/gis-and-gps-for-trailroute-identificationsmall.pdf

Murdock, E. (2004). understanding recreation flow to protect wilderness resources at joshua tree national park. Retrieved from understanding recreation flow to protect wilderness resources at joshua tree national park: http://www.metla.fi/julkaisut/workingpapers/2004/mwp002-18.pdf

Nagarajan, M., \& S, Singh (2009). Assessment of Groundwater Potential Zone Using GIS Technique. Retrieved from Assessment of Groundwater Potential Zone Using GIS Technique: http://environmentportal.in/files/Groundwater\%20potential.pdf

Sattler, S. (2014). GIS for the Bartlett Hills Association: Increasing Knowledge to Enhance Land Management Practices.

Sonoma County Vegetation Mapping and LIDAR (2016). SONOMA VEG MAP. Retrieved from Sonoma County Vegetation Mapping and LIDAR PROGRAM: http://sonomavegmap.org/\#tech_advisers

Sonoma Land Trust (2015). Recreational map project.

Sitzia,T., A. Rizzi, D. Cattaneo, and P. Semenzato (2014). Designing recreational trails in a forest dune habitat using least-costpath analysis at the resolution of visitor sight distance. Retrieved from Urban Forestry \& Urban Greening: http://www.academia.edu/16614290/Designing_recreational_trails_in_a_forest_d une_habitat_using_leastcost_path_analysis_at_the_resolution_of_visitor_sight_distance

The Wildlands Conservancy (1995-2012). The Wildlands Conservancy. Retrieved from http://www.wildlandsconservancy.org/index.html 
Thompson, B. (2014). Shakil Kashem. Retrieved from University of Illinois at UrbanaChampaign: http://shakilkashem.net/gis-projects/spring-2014/thomps48

Sonoma Land Trust (2014). Sonoma Land Trust. Retrieved from http://www.sonomalandtrust.org/index.html

U.S. Forest Service (2008). U.S. Forest Service Trails Management Handbook. Retrieved from U.S. Forest Service Trails Management Handbook: http://www.fs.usda.gov/Internet/FSE_DOCUMENTS/stelprdb5403600.pdf

United States Department of Agriculture (2016). Natural Resources Conservation Service. Retrieved from Natural Resources Conservation Service: http://www.nrcs.usda.gov/wps/portal/nrcs/detail/soils/survey/geo/?cid=nrcs142p2 _053627

US Geological Survey (2016). National Gap Analysis Program (GAP)| Land Cover Data Portal. Retrieved from National Gap Analysis Program (GAP) | Land Cover Data Portal: http:/gapanalysis.usgs.gov/gaplandcover/data/download/ 

